\title{
Aerosol nucleation and its role for clouds and Earth's radiative forcing in the aerosol-climate model ECHAM5-HAM
}

\author{
J. Kazil ${ }^{1, *}$, P. Stier ${ }^{2}$, K. Zhang ${ }^{1}$, J. Quaas ${ }^{1}$, S. Kinne ${ }^{1}$, D. O'Donnell ${ }^{1}$, S. Rast ${ }^{1}$, M. Esch ${ }^{1}$, S. Ferrachat ${ }^{3}$, U. Lohmann ${ }^{3}$, \\ and J. Feichter ${ }^{1}$ \\ ${ }^{1}$ Max Planck Institute for Meteorology, Hamburg, Germany \\ ${ }^{2}$ Atmospheric, Oceanic and Planetary Physics, University of Oxford, UK \\ ${ }^{3}$ Institute for Atmospheric and Climate Science, ETH Zürich, Switzerland \\ *now at: Cooperative Institute for Research in Environmental Sciences (CIRES), \\ University of Colorado, Boulder, Colorado, USA
}

Received: 3 April 2010 - Published in Atmos. Chem. Phys. Discuss.: 10 May 2010

Revised: 16 August 2010 - Accepted: 24 October 2010 - Published: 16 November 2010

\begin{abstract}
Nucleation from the gas phase is an important source of aerosol particles in the Earth's atmosphere, contributing to the number of cloud condensation nuclei, which form cloud droplets. We have implemented in the aerosolclimate model ECHAM5-HAM a new scheme for neutral and charged nucleation of sulfuric acid and water based on laboratory data, and nucleation of an organic compound and sulfuric acid using a parametrization of cluster activation based on field measurements. We give details of the implementation, compare results with observations, and investigate the role of the individual aerosol nucleation mechanisms for clouds and the Earth's radiative forcing. The results of our simulations are most consistent with observations when neutral and charged nucleation of sulfuric acid proceed throughout the troposphere and nucleation due to cluster activation is limited to the forested boundary layer. The globally averaged annual mean contributions of the individual nucleation processes to total absorbed solar short-wave radiation via the direct, semi-direct, indirect cloud-albedo and cloud-lifetime effects in our simulations are $-1.15 \mathrm{~W} / \mathrm{m}^{2}$ for charged $\mathrm{H}_{2} \mathrm{SO}_{4} / \mathrm{H}_{2} \mathrm{O}$ nucleation, $-0.235 \mathrm{~W} / \mathrm{m}^{2}$ for cluster activation, and $-0.05 \mathrm{~W} / \mathrm{m}^{2}$ for neutral $\mathrm{H}_{2} \mathrm{SO}_{4} / \mathrm{H}_{2} \mathrm{O}$ nucleation. The overall effect of nucleation is $-2.55 \mathrm{~W} / \mathrm{m}^{2}$, which exceeds the sum of the individual terms due to feedbacks and interactions in the model. Aerosol nucleation contributes over the oceans with $-2.18 \mathrm{~W} / \mathrm{m}^{2}$ to total absorbed solar short-wave radiation, compared to $-0.37 \mathrm{~W} / \mathrm{m}^{2}$ over land.
\end{abstract}

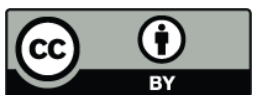

Correspondence to: J. Kazil (jan.kazil@noaa.gov)
We explain the higher effect of aerosol nucleation on Earth's radiative forcing over the oceans with the larger area covered by ocean clouds, due to the larger contrast in albedo between clouds and the ocean surface compared to continents, and the larger susceptibility of pristine clouds owing to the saturation of effects. The large effect of charged nucleation in our simulations is not in contradiction with small effects seen in local measurements: over southern Finland, where cluster activation proceeds efficiently, we find that charged nucleation of sulfuric acid and water contributes on average less than $10 \%$ to ultrafine aerosol concentrations, in good agreement with observations.

\section{Introduction}

Aerosol nucleation from the gas phase is an important source of aerosol particles in the Earth's atmosphere, contributing to the number of cloud condensation nuclei (Kulmala et al., 2004), which form cloud droplets. Nucleation can therefore act upon cloud radiative properties, cloud lifetimes, and precipitation rates via the first (Twomey, 1977) and second (Albrecht, 1989) indirect aerosol effect. However, freshly nucleated particles measure only a few nanometers in diameter, and need to grow to sizes of tens of nanometers in order to participate in atmospherically relevant processes. Depending on the availability of condensable molecules, this process may proceed on time scales between minutes to days. Concurrently, the aerosol particles that formed from the gas phase compete with aerosol particles emitted from the surface for condensable material. Therefore, cloud radiative properties,

Published by Copernicus Publications on behalf of the European Geosciences Union. 
cloud lifetimes, and precipitation rates will depend to various degrees on aerosol nucleation rates and on the individual nucleation pathways.

Laboratory and field studies indicate that multiple nucleation mechanisms proceed in the troposphere (e.g., Eichkorn et al., 2002; O'Dowd et al., 2002; Lee et al., 2003; Lovejoy et al., 2004; Zhang et al., 2004; Kulmala et al., 2006, and further references in the text), and no single mechanism has been found to date which explains all available observations. However, sulfuric acid plays an important role for aerosol nucleation due to its very low vapor pressure in atmospheric conditions: together with water it readily nucleates in cold temperatures (Hanson and Lovejoy, 2006), such as in the upper troposphere (Brock et al., 1995; Clarke and Kapustin, 2002). At warmer temperatures, additional nucleating agents may be required: ubiquitous ions, produced by galactic cosmic rays and by Radon decay stabilize small $\mathrm{H}_{2} \mathrm{SO}_{4} / \mathrm{H}_{2} \mathrm{O}$ clusters, and may initiate nucleation (Lovejoy et al., 2004). Other compounds such as organic molecules (Zhang et al., 2004; Kulmala et al., 2006) and ammonia (Coffman and Hegg, 1995; Ball et al., 1999) have been shown to nucleate together with sulfuric acid, although the contribution of ammonia is controversial (Sakurai et al., 2005; Gaydos et al., 2005; Yu, 2005; Jung et al., 2008; Sihto et al., 2009). Iodine has been shown to drive aerosol nucleation in coastal regions (O'Dowd et al., 2002; Burkholder et al., 2004). Amines (Mäkelä et al., 2001; Murphy et al., 2007; Kurtén et al., 2008) and organic nitrates (Fry et al., 2009) have been discussed as nucleation agents as well. Organic molecules may also nucleate in the absence of sulfuric acid (Burkholder et al., 2007). For a more detailed discussion of aerosol nucleation in the troposphere see Kazil et al. (2008) and references therein.

The importance of nucleation from the gas phase for aerosol on a global scale has been investigated in previous model studies: Spracklen et al. (2006) presented a first assessment of the contribution of aerosol nucleation in the boundary layer and of primary emissions to global and regional concentrations of ultrafine aerosol (defined as particles with dry diameter $>3 \mathrm{~nm}$ ): using the parametrization of nucleation via cluster activation (Kulmala et al., 2006) developed by Sihto et al. (2006), Spracklen et al. were able to well reproduce the occurrence and intensity of aerosol formation events in Hyytiälä, Finland. Furthermore, Spracklen et al. found that particle concentrations in polluted continental regions are dominated by primary particles, while remote continental regions are dominated by nucleated particles, and predicted enhancements in boundary layer ultrafine aerosol due to nucleation over the remote Southern Ocean. Yu and Luo (2009) assessed that nucleation from the gas phase contributes to aerosol concentrations in excess of $80 \%$ in most parts of the troposphere, and Merikanto et al. (2009) estimated that $45 \%$ of global low-level cloud cloud condensation nuclei are derived from aerosol nucleation. Pierce and Adams (2009) demonstrated the impor- tance of reducing uncertainties in primary emissions for the investigation of aerosol nucleation on the global scale, as primary aerosol emissions bear strongly upon aerosol nucleation by removing nucleating and condensable molecules. Spracklen et al. (2008) found that using nucleation due to cluster activation in a global model improves the modeled particle size distribution and total particle number concentration compared to observations at three continental sites in $\mathrm{Eu}-$ rope. Later Spracklen et al. (2010) showed that using aerosol nucleation greatly reduces model bias in aerosol concentrations when compared to a comprehensive set of aerosol observations covering the globe. Merikanto et al. (2010) have investigated the effects of boundary layer particle formation on cloud droplet number and diagnosed the resulting effect on cloud albedo, and found that aerosol nucleation plays a similar role in pre-industrial to present-day conditions on the global scale, but with substantial regional effects. Makkonen et al. (2009) used nucleation via cluster activation as parametrized by Sihto et al. (2006) together with neutral nucleation of sulfuric acid and water (Vehkamäki et al., 2002) in the ECHAM5-HAM model (Stier et al., 2005). They found that aerosol particle number concentrations and, perhaps more importantly, cloud droplet number concentrations in the ECHAM5-HAM model are sensitive to the aerosol nucleation mechanism used.

Global model studies have progressed to investigate the effect of nucleation from the gas phase on Earth's radiative budget via the response of clouds to aerosol: Wang and Penner (2009) conducted simulations for pre-industrial and present-day conditions with different implementations of aerosol nucleation in an aerosol-climate model. They estimated a climate forcing from pre-industrial to present-day conditions via the first indirect aerosol effect ranging from -1.22 to $-2.03 \mathrm{~W} / \mathrm{m}^{2}$ due to various treatments of aerosol nucleation. This large variation shows the importance of well quantifying aerosol nucleation in global models. In addition, Wang and Penner found that the inclusion of cluster activation in the model improved the comparison of cloud top droplet number concentrations from the model with satellite observations over the Southern Oceans, a result that is consistent with Spracklen et al. (2006).

In several global studies, nucleation due to cluster activation, parametrized based on measurements in the forested boundary layer in Hyytiälä, Finland (Sihto et al., 2006) has been used throughout the troposphere or in the global boundary layer. However, nucleation due to cluster activation (Kulmala et al., 2006) requires organic molecules to proceed, which are found at lower concentrations over the oceans and in the free troposphere compared to the forested boundary layer: Rinne et al. (2005), e.g., report 250-500 ppt of isoprene in Hyytiälä, while Matsunaga et al. (2002) observe concentrations between 7.2 and $110 \mathrm{ppt}$ of this compound in marine air. While we do not exclude the possibility that cluster activation, and more generally nucleation involving organics do proceed over the oceans and in the free 
troposphere, it is plausible that owing to the lower concentrations of organic molecules, they proceed there at lower rates than observed in the forested boundary layer. This consideration is supported by the work of Metzger et al. (2010), who obtain a good agreement of ultrafine aerosol in a global model simulation over the continental United States and in its outflow when nucleation involving organics proceeds predominantly in the lower troposphere, rather than farther aloft. Therefore, the parametrization of nucleation due to cluster activation (Sihto et al., 2006), which was developed from measurements in the forested boundary layer, may overestimate the corresponding particle formation rates at locations with low concentrations of organic molecules.

Nucleation mechanisms that do not require organic molecules, such as neutral and charged nucleation of sulfuric acid and water (Lovejoy et al., 2004; Hanson and Lovejoy, 2006) may be more efficient at locations low in organics than nucleation mechanisms that do require organics. Yu et al. (2008) have investigated ion-mediated aerosol nucleation of sulfuric acid and water in a global chemical transport model, and showed, based on a comprehensive comparison with observations that this process may account for many of the observed boundary layer nucleation events. In a detailed modeling study and comparison with field data, Yu and Turco (2008) found that ion-mediated nucleation may even play a dominant role in new particle formation in the forested boundary layer.

Here, we investigate in a global climate model three aerosol nucleation processes that are described based on laboratory or field measurements. Neutral and charged nucleation of sulfuric acid and water (Lovejoy et al., 2004; Hanson and Lovejoy, 2006), and nucleation of an organic compound and sulfuric acid via cluster activation (Kulmala et al., 2006) were integrated into the aerosol-climate model ECHAM5HAM (Stier et al., 2005). Neutral and charged nucleation of sulfuric acid and water proceed in the model throughout the troposphere at rates calculated from the underlying laboratory thermochemical data with the method of Kazil and Lovejoy (2007). Nucleation from cluster activation is limited to the forested boundary layer and proceeds at rates determined by a parametrization of field measurements in the boreal forest (Sihto et al., 2006).

The purpose of this study is to identify the role of new particle formation from these nucleation mechanisms for aerosol concentrations, cloud properties, and Earth's radiative forcing, and to assess their ability to explain observations. The paper is organized in the following way: a brief description of ECHAM5-HAM and an account of the implementation of aerosol nucleation in the model is given in Sect. 2. The simulations are introduced in Sect. 3, and their results discussed and compared to observations in Sect. 4. Conclusions are given in Sect. 5 .

\section{Model description}

\subsection{Brief overview of ECHAM5-HAM}

The microphysical aerosol module HAM (Stier et al., 2005) in the general circulation model ECHAM5 (Roeckner et al., 2003) predicts the evolution of an ensemble of seven interacting internally and externally mixed log-normal aerosol modes. In the current setup, the components comprise sulfate, black carbon, particulate organic matter, sea salt, and mineral dust. The modes are composed either of hydrophobic compounds or of an internal mixture of hydrophobic and hydrophilic compounds. The aerosol microphysics module M7 (Vignati et al., 2004) calculates coagulation among the aerosol modes, the water uptake of the aerosol particles, and their growth by condensation of gas phase sulfuric acid. An improved time integration scheme for gas phase sulfuric acid is used in ECHAM5-HAM, described in detail in Kokkola et al. (2009), who also compare the modal approach of M7 with sectional schemes in ECHAM5-HAM. The uptake of water is calculated in the present ECHAM5-HAM using the $\kappa$-Köhler theory method of Petters and Kreidenweis (2007). This approach assigns a hygroscopicity parameter $\kappa$ to each substance. The overall $\kappa$ value of an internally mixed particle is obtained by the volume weighting of its component species. The growth factor is calculated as a function of temperature, relative humidity (of the cloud-free fraction of the grid box), particle dry diameter, and the overall $\kappa$. Sulfate, sea salt and organics may contribute to water uptake; their respective $\kappa$ values are taken as the mean growth factor derived values presented in Petters and Kreidenweis (2007).

With the exception of sulfur compounds, aerosol mass originates from primary emissions in the present version of ECHAM5-HAM. This is a realistic assumption for most of the treated species, but may result in an underestimation of particulate organic matter. The sulfur cycle model (Feichter et al., 1996) of ECHAM5-HAM treats the prognostic variables dimethyl sulfide (DMS), sulfur dioxide $\left(\mathrm{SO}_{2}\right)$, and sulfate $\left(\mathrm{SO}_{4}^{=}\right)$, and their gas and aqueous phase reaction pathways using pre-calculated monthly mean oxidant fields (Stier et al., 2005).

Aerosol radiative properties, as well as the sink processes dry deposition, sedimentation, and wet deposition are parametrized in dependence on the prognostic aerosol size distribution, composition, and mixing state and coupled to the ECHAM5 meteorology. Aerosol radiative properties are calculated in the framework of Mie theory (Stier et al., 2005, 2007). The effective complex refractive indices and the Mie size parameters for each mode serve as input to look-up tables for the aerosol radiative properties that are provided online to the ECHAM5 radiation scheme.

Aerosol wet deposition is parametrized in terms of the aerosol size distribution and mixing state via modespecific scavenging ratios, specifying embedded and interstitial aerosol fractions in the cloudy part of a grid box and 
Table 1. Grid of parameters on which the particle formation rate from neutral and charged $\mathrm{H}_{2} \mathrm{SO}_{4} / \mathrm{H}_{2} \mathrm{O}$ nucleation is defined. Sulfuric acid concentrations up to $5 \times 10^{9} \mathrm{~cm}^{-3}$, although not common in the atmosphere, are covered in order to accommodate the model spin-up phase, when the $\mathrm{H}_{2} \mathrm{SO}_{4}$ condensation sink is very small and $\mathrm{H}_{2} \mathrm{SO}_{4}$ concentrations high. The relative humidity lower limit of $1 \%$ covers locations up to a pressure level of $\sim 30 \mathrm{hPa}$, above which nucleation is negligible in background conditions. For stratospheric applications, e.g. simulations of large volcanic eruptions, a grid extending to relative humidities below $1 \%$ is required.

\begin{tabular}{lllc}
\hline & minimum & maximum & number of grid points \\
\hline Temperature & $180 \mathrm{~K}$ & $320 \mathrm{~K}$ & 40 \\
Relative humidity & $1 \%$ & $101 \%$ & 40 \\
$\mathrm{H}_{2} \mathrm{SO}_{4}$ concentration & $10^{5} \mathrm{~cm}^{-3}$ & $5 \times 10^{9} \mathrm{~cm}^{-3}$ & 40 \\
$\mathrm{H}_{2} \mathrm{SO}_{4}$ condensation sink & $0 \mathrm{~s}^{-1}$ & $0.1 \mathrm{~s}^{-1}$ & 40 \\
Ionization rate & $1 \mathrm{~cm}^{-3} \mathrm{~s}^{-1}$ & $55 \mathrm{~cm}^{-3} \mathrm{~s}^{-1}$ & 20 \\
\hline
\end{tabular}

in convective updrafts. The actual wet deposition is calculated from the resulting embedded aerosol content based on the precipitation formation and re-evaporation calculated by the ECHAM5 cloud scheme. Aerosol and gas dry deposition velocities are calculated based on a serial resistance approach (Stier et al., 2005).

The stratiform cloud scheme in ECHAM5-HAM consists of prognostic equations for the water phases (vapor, liquid, solid), bulk cloud microphysics (Lohmann and Roeckner, 1996), and an empirical cloud cover scheme (Sundqvist et al., 1989). The cloud microphysics scheme includes phase changes between the water components and precipitation processes (autoconversion, accretion, aggregation). Moreover, evaporation of rain and melting of snow are considered, as well as sedimentation of cloud ice. It also includes prognostic equations of the number concentrations of cloud droplets and ice crystals and has been coupled to the aerosol scheme HAM (Lohmann et al., 2007). It assumes that cirrus clouds form by homogeneous freezing of supercooled solution droplets (Lohmann et al., 2008), which is the dominant freezing mechanism for cirrus clouds (Kärcher and Ström, 2003).

\subsection{Aerosol nucleation in ECHAM5-HAM}

Neutral and charged $\mathrm{H}_{2} \mathrm{SO}_{4} / \mathrm{H}_{2} \mathrm{O}$ nucleation in ECHAM5HAM is implemented based on thermochemical parameters (entropy and enthalpy change) for the uptake and loss of $\mathrm{H}_{2} \mathrm{SO}_{4}$ and $\mathrm{H}_{2} \mathrm{O}$ molecules by small neutral and negatively charged $\mathrm{H}_{2} \mathrm{SO}_{4} / \mathrm{H}_{2} \mathrm{O}$ clusters, measured in the laboratory (Curtius et al., 2001; Froyd and Lovejoy, 2003; Hanson and Lovejoy, 2006). These thermochemical data were used in the method of Kazil and Lovejoy (2007) to generate a table of steady-state formation rates of neutral and charged $\mathrm{H}_{2} \mathrm{SO}_{4} / \mathrm{H}_{2} \mathrm{O}$ particles with $15 \mathrm{H}_{2} \mathrm{SO}_{4}$ molecules, as a function of temperature, relative humidity, gas phase sulfuric acid concentration, $\mathrm{H}_{2} \mathrm{SO}_{4}$ condensation sink onto preexisting aerosol, and ionization rate. The table is interpolated in ECHAM5-HAM to obtain the particle formation rate in given ambient conditions. The grid on which the table is defined is given in Table 1. Similar tables as used here have been developed by Yu (2006), Yu et al. (2008), and $\mathrm{Yu}$ (2010). The formation rate of particles with $15 \mathrm{H}_{2} \mathrm{SO}_{4}$ molecules is used instead of the nucleation rate, as the latter would require the interpolation of an additional table giving the $\mathrm{H}_{2} \mathrm{SO}_{4}$ content of the nucleating particles, resulting in an increased computational burden and additional interpolation errors. The number of $15 \mathrm{H}_{2} \mathrm{SO}_{4}$ molecules for the forming particles was chosen because it covers the $\mathrm{H}_{2} \mathrm{SO}_{4}$ content of the critical $\mathrm{H}_{2} \mathrm{SO}_{4} / \mathrm{H}_{2} \mathrm{O}$ cluster in atmospheric conditions in which nucleation is efficient; our calculations show that the nucleation rate is negligibly small when the critical cluster contains more than $15 \mathrm{H}_{2} \mathrm{SO}_{4}$ molecules. However, in such conditions, the table would give the formation rate of subcritical particles; we then set the tabulated particle formation rate to zero.

The removal of nucleating particles with fewer than $15 \mathrm{H}_{2} \mathrm{SO}_{4}$ molecules by pre-existing aerosol and the resulting reduction of the particle formation rate is accounted for in the calculation of the particle formation rate table using the $\mathrm{H}_{2} \mathrm{SO}_{4}$ condensation sink $s$ onto pre-existing aerosol via the formula (Kazil and Lovejoy, 2007)

$s_{i} \approx \frac{k_{i}(\rho, D)}{k_{1}(\rho, D)} s, \quad 1<i<15$.

The $s_{i}$ are sinks for coagulation of particles containing $i$ $\mathrm{H}_{2} \mathrm{SO}_{4}$ molecules onto pre-existing aerosol, and $k_{i}(\rho, D)$ the rate coefficients for Brownian coagulation (Fuchs, 1964) of these particles with a particle with the mass density $\rho$ and the diameter $D$, which represents the pre-existing aerosol population. The values $\rho=2 \mathrm{gcm}^{-3}$ and $D=165 \mathrm{~nm}$, which are consistent with observations of marine aerosol (Hegg et al., 1997; Heintzenberg et al., 2000) have been used in the calculation of the particle formation rate table. While this approach reduces the information on pre-existing aerosol needed to calculate the particle formation rates, it may result in errors if the choice of $\rho$ and $D$ used to describe the preexisting aerosol in the calculation of the particle formation rate table does not well describe the pre-existing aerosol in a model run. The errors could become most pronounced when 
the pre-existing aerosol size distribution (with a given $\mathrm{H}_{2} \mathrm{SO}_{4}$ condensation sink $s$ ) in the model run is dominated by very small particles (diameters $\ll 100 \mathrm{~nm}$ ), when the loss of nucleating clusters onto the pre-existing aerosol takes place in the free molecular regime, while the assumed diameter of $D=165 \mathrm{~nm}$ used for the calculation of the tabulated particle formation rate implies less rapid loss (at the same $\mathrm{H}_{2} \mathrm{SO}_{4}$ condensation sink $s$ ) in the diffusion-limited regime. The impact of the assumed mass density $\rho$ and diameter $D$ of pre-existing aerosol on the ability of the model to reproduce observations is discussed in Sect. 4.

Nucleation via cluster activation (Kulmala et al., 2006) is implemented in ECHAM5-HAM using the parametrization of Sihto et al. (2006): the nucleation rate $J_{A}$ of clusters containing one $\mathrm{H}_{2} \mathrm{SO}_{4}$ molecule and an organic compound is calculated as

$J_{A}=A \cdot\left[\mathrm{H}_{2} \mathrm{SO}_{4}\right]$

where $A=10^{-6} \mathrm{~s}^{-1}$ is the median coefficient determined from particle formation rates and sulfuric acid gas phase concentrations during the QUEST II campaign in Hyytiälä (Sihto et al., 2006). This formulation does not represent a possible dependence of cluster activation on the concentration of gas phase organic molecules, and may overestimate the resulting nucleation rate at locations where organic molecules are scarcer than in the boreal forest, such as in the free troposphere and over the oceans. We therefore limit cluster activation to the forested boundary layer: in every model grid volume below the boundary layer height, the number of particles from cluster activation is scaled by the fraction of land covered by forest. The forest fraction is taken from a land use table.

The number and mass of the newly formed particles from the different nucleation processes are committed to the nucleation mode of the ECHAM5-HAM aerosol microphysics module M7 (Vignati et al., 2004) in cloud-free portions of the model grid volumes, while in the cloudy portions, all gas phase $\mathrm{H}_{2} \mathrm{SO}_{4}$ is removed by condensation and distributed onto the aerosol modes, with no nucleation taking place. None of the nucleation processes is preferred in terms of the mass or number of the particles produced: the different nucleation mechanisms in ECHAM5-HAM operate with the same sulfuric acid gas phase concentration, and the loss of nucleating particles by self-coagulation and onto pre-existing aerosol is accounted for during their growth.

\subsection{Galactic cosmic rays}

Galactic cosmic rays (GCR) are, together with the decay of Radon the main source of ions in the troposphere. The GCR ionization rate is anti-correlated with the decadal solar activity cycle (Forbush, 1954; Neher and Forbush, 1958). In the present implementation, ECHAM5-HAM determines the GCR ionization rate $q$ based on solar minimum and maximum GCR ionization rates $q_{\min }$ and $q_{\max }$, calculated with
Table 2. List of simulations. Filled circles indicate that a given particle formation mechanism is used in a simulation.

\begin{tabular}{lllllll}
\hline & $\mathcal{S}_{\text {ref }}$ & $\mathcal{S}_{0}$ & $\mathcal{S}_{\text {non }}$ & $\mathcal{S}_{\text {noc }}$ & $\mathcal{S}_{\text {noact }}$ & $\mathcal{S}_{\text {act }}$ \\
\hline $\begin{array}{l}\mathrm{H}_{2} \mathrm{SO}_{4} / \mathrm{H}_{2} \mathrm{O} \text { nucleation } \\
\text { neutral } \\
\text { charged }\end{array}$ & $\bullet$ & & & & & \\
$\begin{array}{l}\text { Cluster activation } \\
\text { in the forested boundary layer } \\
\text { elsewhere in the troposphere }\end{array}$ & $\bullet$ & & $\bullet$ & $\bullet$ & & $\bullet$ \\
\hline
\end{tabular}

the PLOTINUS code (O'Brien, 2005) for heliocentric potentials (Gleeson and Axford, 1968) of 464/1346 MV, respectively. $q_{\min }$ and $q_{\max }$ are tabulated as functions of the mass column density $\left(10-1100 \mathrm{~g} \mathrm{~cm}^{-2}\right)$ and vertical cutoff rigidity $(0-14.9 \mathrm{GV})$ and interpolated for the model grid volume centers. The GEOPACK 2005 software suite (Tsyganenko, 2005) and the IGRF-10 coefficients (Maus et al., 2005) for the period 1965 to 2010 are used to calculate the orientation of the Earth magnetic dipole for a given date and the corresponding transformation between geographic and geomagnetic coordinates. For dates before 1965 and after 2010, the IGRF-10 coefficients for the year 1965 and 2010 are used, respectively. The modulation of the GCR ionization rate $q$ by the decadal solar activity cycle is parametrized as

$q=\frac{(1-a) q_{\min }+(1+a) q_{\max }}{2}$

with the solar activity parameter $a$,

$a=\cos \left(2 \pi \frac{t-1991}{11}\right)$,

where $t$ is the time in years. This approach does not capture short-term variations in the GCR intensity and ionization rate and the variability in the length of the decadal solar activity cycle.

\section{Simulations}

A series of ECHAM5-HAM simulations (Table 2) will be evaluated for the role of the considered particle formation mechanisms for clouds and radiative forcing and their ability to explain observations. The simulations cover the year 2000 with a spin-up period of three months, and were nudged (Jeuken et al., 1996) towards ERA-40 reanalysis data (Simmons and Gibson, 2000) in order to produce the same large scale meteorology (wind fields and temperature). Without nudging, averaging over longer simulation periods would be required to eliminate internal variability of the model to single out aerosol effects on clouds. Monthly mean AMIP II sea surface temperatures and sea ice cover (Taylor et al., 2000) were used. Anthropogenic sulfur is emitted with $97.5 \%$ as $\mathrm{SO}_{2}$ and $2.5 \%$ as particulate $\mathrm{SO}_{4}^{=}$following the AeroCom recommendation (Dentener et al., 2006). Other primary aerosol emissions include dust, sea salt, and black and 
Table 3. Contributions of individual particle formation processes to a model quantity $Q$, calculated from the simulations listed in Table 2 .

\begin{tabular}{llc}
\hline Process & \multicolumn{2}{c}{ Contribution to $Q$} \\
& \multicolumn{1}{c}{ absolute } & relative \\
\hline All nucleation & $Q\left(\mathcal{S}_{\text {ref }}\right)-Q\left(\mathcal{S}_{0}\right)$ & $\frac{Q\left(\mathcal{S}_{\text {ref }}\right)-Q\left(\mathcal{S}_{0}\right)}{Q\left(\mathcal{S}_{\text {ref }}\right)}$ \\
Neutral $\mathrm{H}_{2} \mathrm{SO}_{4} / \mathrm{H}_{2} \mathrm{O}$ nucleation & $Q\left(\mathcal{S}_{\text {ref }}\right)-Q\left(\mathcal{S}_{\text {non }}\right)$ & $\frac{Q\left(\mathcal{S}_{\text {ref }}\right)-Q\left(\mathcal{S}_{\text {non }}\right)}{Q\left(\mathcal{S}_{\text {reff }}\right)}$ \\
Charged $\mathrm{H}_{2} \mathrm{SO}_{4} / \mathrm{H}_{2} \mathrm{O}$ nucleation & $Q\left(\mathcal{S}_{\text {ref }}\right)-Q\left(\mathcal{S}_{\text {noc }}\right)$ & $\frac{Q\left(\mathcal{S}_{\text {ref }}\right)-Q\left(\mathcal{S}_{\text {noc }}\right)}{Q\left(\mathcal{S}_{\text {ref }}\right)}$ \\
Cluster activation & $Q\left(\mathcal{S}_{\text {ref }}\right)-Q\left(\mathcal{S}_{\text {noact }}\right)$ & $\frac{Q\left(\mathcal{S}_{\text {ref }}\right)-Q\left(\mathcal{S}_{\text {noact }}\right)}{Q\left(\mathcal{S}_{\text {ref }}\right)}$ \\
\hline
\end{tabular}

Table 4. Regions of the Pacific Ocean over which model results are compared with observations; land areas are excluded.

\begin{tabular}{lrrrr}
\hline & \multicolumn{2}{c}{ Longitude $\left({ }^{\circ} \mathrm{E}\right)$} & \multicolumn{2}{c}{ Latitude $\left({ }^{\circ} \mathrm{N}\right)$} \\
& minimum & maximum & minimum & maximum \\
\hline Northern Pacific & 190 & 240 & 20 & 70 \\
Tropical Pacific & 150 & 270 & -20 & 20 \\
Southern Pacific & 135 & 270 & -70 & -20 \\
\hline
\end{tabular}

organic carbon (Stier et al., 2005). The model domain is resolved with 19 vertical levels (L19) between the surface and $10 \mathrm{hPa}$, a horizontal grid with a mean resolution of $2.8^{\circ}$ (spherical harmonics triangular truncation at wave number 42, T42), and a time step of $1800 \mathrm{~s}$.

In a reference simulation $\left(\mathcal{S}_{\text {ref }}\right)$, new particles form from the gas phase due to neutral and charged $\mathrm{H}_{2} \mathrm{SO}_{4} / \mathrm{H}_{2} \mathrm{O}$ nucleation, and due to cluster activation in the forested boundary layer. In test simulations, individual nucleation processes were modified (Table 2), and the response of model quantities evaluated, as well as the ability of the test simulations to explain observations. The contribution of an individual process to a model quantity is estimated by subtracting the results with the process switched off from the results of the reference simulation (see Table 3). This approach is an approximation, as switching off a process may reinforce or dampen the effect of the remaining processes (Stier et al., 2006), but allows ranking the processes in terms of relevance, resolved by location and time. In addition to the simulations in Table 2, sensitivity studies with modifications of the model were conducted which will be discussed in the text.

\section{Results, comparison with observations, and discussion}

\subsection{Ultrafine aerosol}

Aerosol nucleation often occurs on spatial and temporal scales that are smaller than those typically resolved by global models, due to specific meteorological, topographic, and transport phenomena (O'Dowd et al., 1998; Weber et al.,
2003; Petters et al., 2006; Jimi et al., 2008; Venzac et al., 2008), and due to the non-linear nature of nucleation processes. However, nucleation events may also occur over spatial scales of several hundred kilometers (Birmili et al., 2003; Vana et al., 2004; Qian et al., 2007) in favorable meteorological conditions. Therefore, measurements of aerosol nucleation and of the resulting particle concentrations that are limited in space and time need not be representative of the same quantities on scales which global models resolve. A data set for the evaluation of aerosol nucleation in a global model will therefore ideally cover large regions where nucleation occurs frequently under similar meteorological conditions which are represented in the model. Clarke and Kapustin (2002) have compiled a comprehensive set of altitude-resolved measurements of ultrafine aerosol particles (defined as particles with dry diameter $>3 \mathrm{~nm}$ ) from the years 1990 to 1999 over the Pacific Ocean. These aerosol profiles are shaped by aerosol nucleation in convective outflow (Clarke and Kapustin, 2002) and cover large areas with a comparably homogeneous meteorology, hence constitute ideal reference values for evaluating the aerosol nucleation schemes in ECHAM5-HAM. This data set has the additional advantage that it covers regions where nucleation mechanisms that are not accounted for in this study, such as involving ammonia, amines, or organic nitrates are less likely to proceed due to the distance to the important land-bound sources of these compounds.

Figure 1a compares aerosol concentrations from the reference simulation $\mathcal{S}_{\text {ref }}$, integrated over their size distribution starting at the measurement cutoff ( $3 \mathrm{~nm}$ dry diameter), for three regions of the Pacific (Table 4), with the data of Clarke and Kapustin (2002). The model overestimates the particle concentrations, most strongly over the northern and southern Pacific, and less so in the tropics, but the increase of concentrations with altitude is consistent with the observations. Near-surface aerosol concentrations are very well reproduced. Possible reasons for the overestimation of the ultrafine aerosol include overestimated $\mathrm{SO}_{2}$ concentrations, underestimated loss rates onto aerosol and cloud particles, overestimated particle formation rates, and specifics of the M7 aerosol microphysics module, which we discuss in the following. 

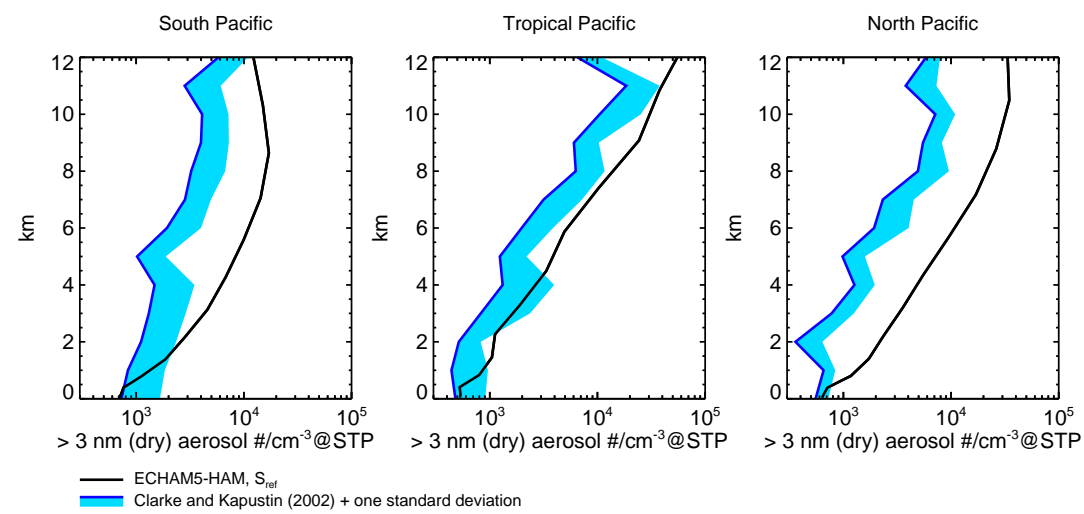

a
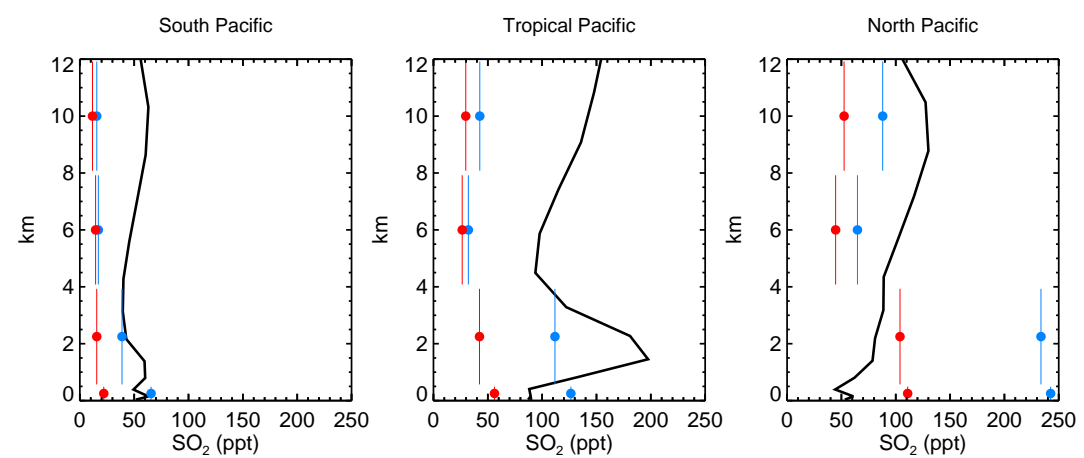

b

- $1991-1996$ arithmetic mean of $5^{\circ} \times 5^{\circ}$ data (Thornton et al., 1999)

- 1991-1996 geometric mean of $5^{\circ} \times 5^{\circ}$ data (Thornton et al., 1999)

Fig. 1. Comparison of annual mean model results from simulation $\mathcal{S}_{\text {ref }}$ with observations in three regions of the Pacific Ocean. (a) Model concentration of ultrafine aerosol particles, and observations (Clarke and Kapustin, 2002). (b) Model $\mathrm{SO}_{2}$ number mixing ratio and observations from Thornton et al. (1999), grouped in the altitude bands $0-0.5 \mathrm{~km}, 0.5-4 \mathrm{~km}, 4-8 \mathrm{~km}$, and $8-12 \mathrm{~km}$, indicated by vertical bars, in blue (arithmetic mean) and red (geometric mean).

Thornton et al. (1999) give $\mathrm{SO}_{2}$ measurements over the Pacific for the years 1991-1996 from campaigns that also contributed to the Clarke and Kapustin (2002) ultrafine aerosol data. We use the Thornton et al. (1999) $\mathrm{SO}_{2}$ data grouped in four altitude bands $(0-0.5 \mathrm{~km}, 0.5-4 \mathrm{~km}, 4-8 \mathrm{~km}$, and $8-12 \mathrm{~km}$ ) and in the latitude and longitude bands given in Table 4. Figure $1 \mathrm{~b}$ compares $\mathrm{SO}_{2}$ from the reference simulation $\mathcal{S}_{\text {ref }}$ in the three regions of the Pacific given in Table 4 with the Thornton et al. (1999) data. The model significantly overestimates $\mathrm{SO}_{2}$ above $4 \mathrm{~km}$. Below this altitude, the comparison is mixed: the model matches the observations fairly well in the south Pacific, less so in the tropics, and underestimates the $\mathrm{SO}_{2}$ in the north Pacific.

In order to evaluate the role of the high $\mathrm{SO}_{2}$ for the high ultrafine aerosol concentrations, we have repeated the simulation $\mathcal{S}_{\text {ref }}$ with global $\mathrm{SO}_{2}$ emissions reduced by a factor of 0.5 (Fig. 2). This reduction leads to a much improved agreement of simulated and observed $\mathrm{SO}_{2}$ (Fig. 2a), but the resulting lower $\mathrm{SO}_{2}$ concentrations have only a small effect on the ultrafine aerosol concentrations (Fig. 2b). This limited sensitivity can be explained as follows: the reduced $\mathrm{SO}_{2}$ not only leads to a lower $\mathrm{H}_{2} \mathrm{SO}_{4}$ production, but concurrently to a reduced aerosol sulfate mass, and consequently to a reduced aerosol $\mathrm{H}_{2} \mathrm{SO}_{4}$ condensation sink (Fig. 2c). This blunts the response of aerosol nucleation rates because the lower $\mathrm{H}_{2} \mathrm{SO}_{4}$ condensation sink reduces the loss of gas phase $\mathrm{H}_{2} \mathrm{SO}_{4}$ and of nucleating particles. This is seen in the $\mathrm{H}_{2} \mathrm{SO}_{4}$ concentrations (Fig. 2d), which respond with a lower relative decrease than $\mathrm{SO}_{2}$ (Fig. 2a) to the reduced $\mathrm{SO}_{2}$ emissions. We therefore conclude that the high ultrafine aerosol concentrations in the model are most likely not caused by overestimated $\mathrm{SO}_{2}$ emissions, nor by underestimated dry and wet deposition of $\mathrm{SO}_{2}$, as increasing the rate of these processes would also reduce the aerosol $\mathrm{H}_{2} \mathrm{SO}_{4}$ sink.

Conversely, an underestimation of processes in the model which reduce $\mathrm{SO}_{2}$ concentrations on the one hand and increase sulfate aerosol mass and thus the aerosol $\mathrm{H}_{2} \mathrm{SO}_{4}$ condensation sink on the other could explain the high ultrafine aerosol concentrations. The two such processes are gas and aqueous phase oxidation of $\mathrm{SO}_{2}$. We have conducted test simulations in which we increased individually the rate of these processes by a factor of two. In the simulation with 

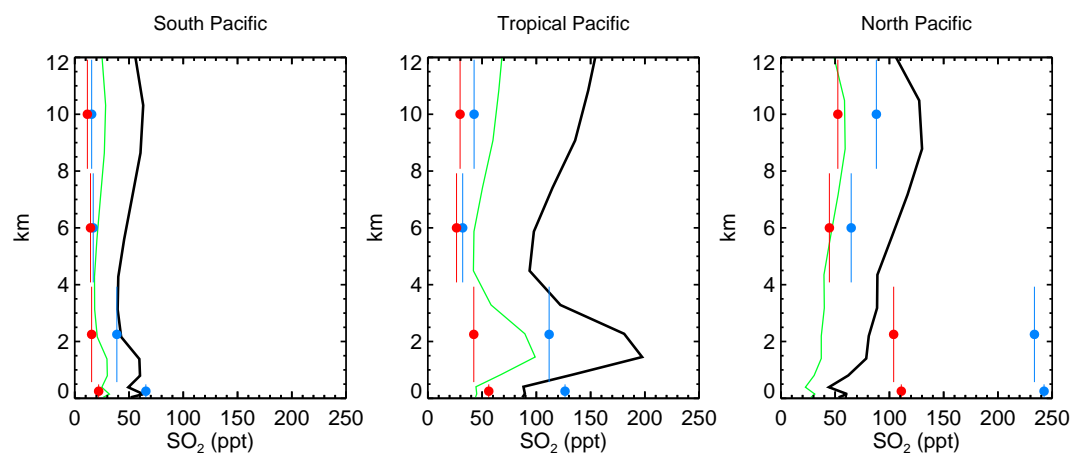

a

ECHAM5-HAM, S

ECHAM5-HAM, $\mathrm{S}_{\text {ret }}, \mathrm{SO}_{2}$ emissions reduced by factor of 0.5 - $1991-1996$ arithmetic mean of $5^{\circ} \times 5^{\circ}$ data (Thornton et al., 1999)
- $1991-1996$ geometric mean of $5^{\circ} \times 5^{\circ}$ data (Thornton et al., 1999)

South Pacific

Tropical Pacific
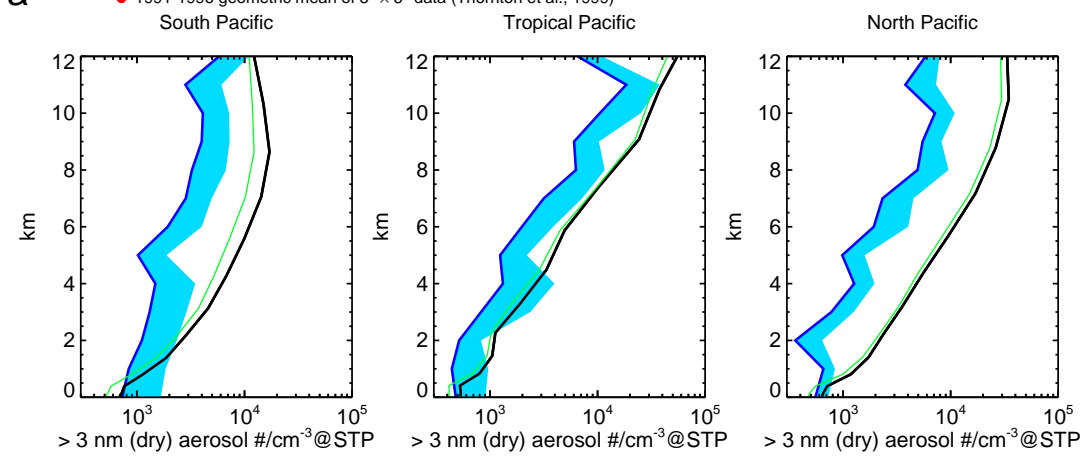

b

- ECHAM5-HAM, $\mathrm{S}_{\text {r }}$ ECHAM5-HAM, $\mathrm{S}_{\mathrm{ret}}, \mathrm{SO}_{2}$ emissions reduced by factor of 0.5

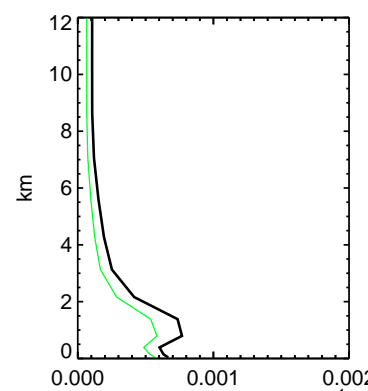
South Pacific

Tropical Pacific

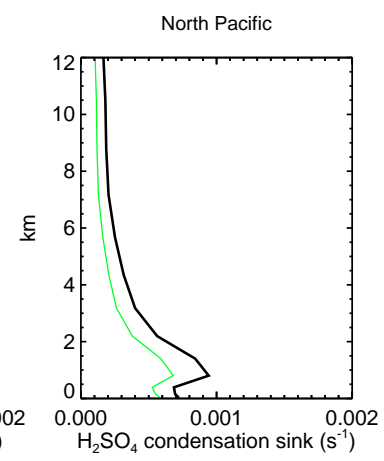

$\mathrm{H}_{2} \mathrm{SO}_{4}$ condensation sink $\left(\mathrm{s}^{-1}\right)$

- ECHAM5-HAM, $S$

South Pacific

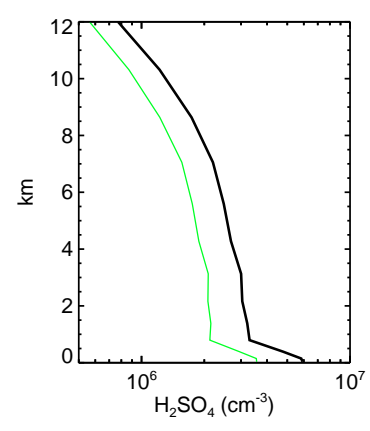

- ECHAM5-HAM, $\mathrm{S}_{\text {re }}$

ECHAM5-HAM, $\mathrm{S}_{\text {ret }}, \mathrm{SO}_{2}$ emissions reduced by factor of 0.5

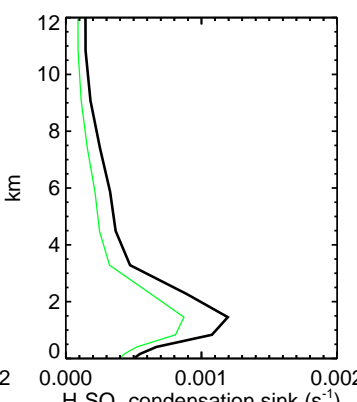

$\mathrm{H}_{2} \mathrm{SO}_{4}$ condensation sink $\left(\mathrm{s}^{-1}\right)$

$\mathrm{H}_{2} \mathrm{SO}_{4}$ condensation sink $\left(\mathrm{s}^{-1}\right)$

d
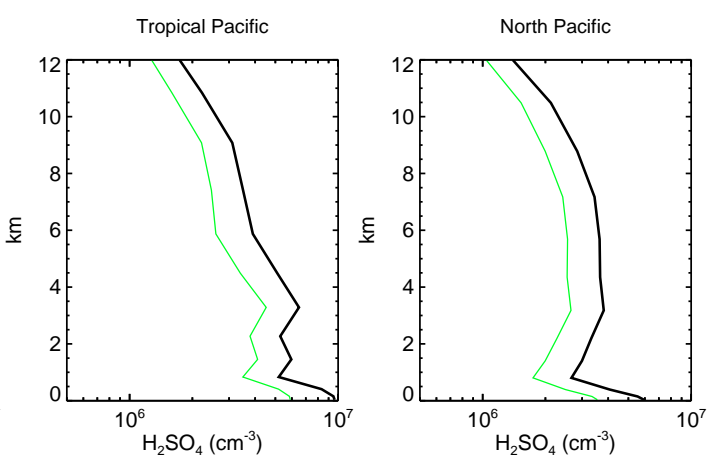

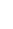

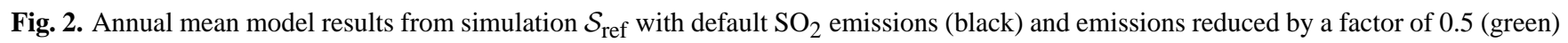
in three regions of the Pacific Ocean. (a) $\mathrm{SO}_{2}$ number mixing ratio. (b) Ultrafine aerosol concentration. (c) $\mathrm{H}_{2} \mathrm{SO}_{4}$ condensation sink. (d) $\mathrm{H}_{2} \mathrm{SO}_{4}$ concentration. 

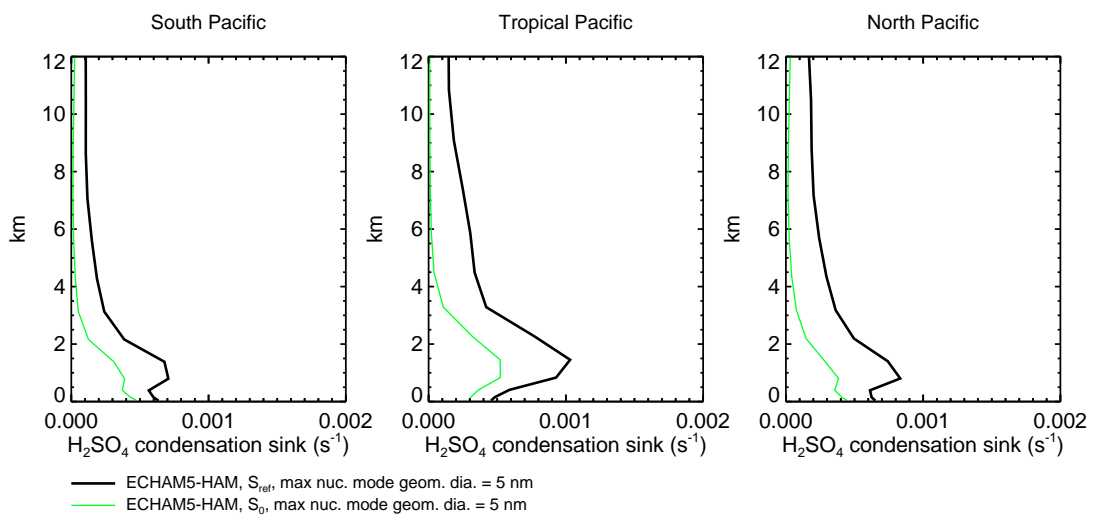

Fig. 3. Comparison of annual mean aerosol $\mathrm{H}_{2} \mathrm{SO}_{4}$ condensation sink from simulation $\mathcal{S}_{\text {ref }}$ (black) with $\mathcal{S}_{0}$ (green) in three regions of the Pacific Ocean.

faster gas phase oxidation of $\mathrm{SO}_{2}$, the $\mathrm{SO}_{2}$ concentrations were in much better agreement with the observations, however, in neither simulation were the ultrafine aerosol concentrations significantly reduced.

We can also exclude that the loss of $\mathrm{H}_{2} \mathrm{SO}_{4}$ and of freshly nucleated particles onto primary aerosol is too low in the model and thereby causes the overestimation of the ultrafine aerosol particles: cloud processes in (deep) convection are extremely efficient in removing sea salt particles, which are the predominant primary aerosol over the Pacific. As a consequence, primary aerosol particles do not contribute significantly to the $\mathrm{H}_{2} \mathrm{SO}_{4}$ condensation sink (Fig. 3): in the simulation $\mathcal{S}_{0}$, where nucleation is switched off, and all aerosol particles originate from surface emissions, the $\mathrm{H}_{2} \mathrm{SO}_{4}$ condensation sink is negligible compared to the reference simu-

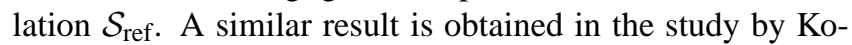
rhonen et al. (2010), who show that injection of artificial sea spray aerosol near the ocean surface has no effect on $\mathrm{H}_{2} \mathrm{SO}_{4}$ and aerosol concentrations above $4 \mathrm{~km}$.

Another possible explanation for the high ultrafine aerosol concentrations in the model are overestimated particle formation rates due to errors in their implementation. We have mentioned in Sect. 2 that the particular choice of mass density $\rho$ and diameter $D$ (Eq. 1), which are used to describe the pre-existing aerosol population in the calculation of the particle formation rate table, may lead to errors when this $\rho$ and $D$ do not well describe the aerosol size distribution in the model run. To investigate this, we have re-calculated the particle formation rate table using the combinations $\rho=1.2 \mathrm{gcm}^{-3}$, $D=165 \mathrm{~nm}$, and $\rho=2 \mathrm{gcm}^{-3}, D=5 \mathrm{~nm}$, and repeated the simulation $\mathcal{S}_{\text {ref. }}$ This change has no effect on the annual mean ultrafine aerosol concentrations that are compared with the observations of Clarke and Kapustin (2002).

A related source of errors may be a too coarse resolution of the particle formation rate table (Table 1). We have recalculated the table with the resolution increased by a factor of 1.5 in each dimension. This change has no effect on the annual mean ultrafine aerosol concentrations that are com- pared with the observations of Clarke and Kapustin (2002).

Systematic errors in the experimental data (entropy and enthalpy change) measured in the laboratory that are used to calculate the formation rates of the neutral and charged $\mathrm{H}_{2} \mathrm{SO}_{4} / \mathrm{H}_{2} \mathrm{O}$ particles could be a reason for the overestimation of the ultrafine aerosol concentrations in the model as well. Froyd and Lovejoy (2003) give an estimated total uncertainty of $\pm 1 \mathrm{kcal} \mathrm{mol}^{-1}$ in the measured Gibbs' free energy change $\Delta G^{\circ}$ for the uptake of $\mathrm{H}_{2} \mathrm{SO}_{4}$ by negative $\mathrm{H}_{2} \mathrm{SO}_{4} / \mathrm{H}_{2} \mathrm{O}$ clusters, representing both precision and systematic error. We have re-calculated the particle formation rate table using enthalpy change values $\Delta H^{\circ}$ for the uptake of $\mathrm{H}_{2} \mathrm{SO}_{4}$ by neutral and negative $\mathrm{H}_{2} \mathrm{SO}_{4} / \mathrm{H}_{2} \mathrm{O}$ clusters (Froyd and Lovejoy, 2003; Hanson and Lovejoy, 2006) that were increased by $1 \mathrm{kcal} \mathrm{mol}^{-1}$, thereby increasing $\Delta G^{\circ}$ by the same amount and reducing the stability of the $\mathrm{H}_{2} \mathrm{SO}_{4} / \mathrm{H}_{2} \mathrm{O}$ clusters and their formation rates, and repeated the simulation $\mathcal{S}_{\text {ref }}$. However, the resulting ultrafine aerosol concentrations were only mildly reduced (Fig. 4a), likely because most of these particles form when gas phase $\mathrm{H}_{2} \mathrm{SO}_{4}$ is sufficiently high so that nucleation takes place in the kinetic regime, where it is comparably insensitive to the cluster formation thermochemical parameters.

However, nucleation parametrizations may exhibit errors in excess of one order of magnitude due to underlying uncertainties. We have repeated simulation $\mathcal{S}_{\text {ref }}$ with neutral and charged $\mathrm{H}_{2} \mathrm{SO}_{4} / \mathrm{H}_{2} \mathrm{O}$ particle formation rates reduced to $1 / 10$ of their original values. With this reduction, the ultrafine aerosol concentrations agree much better with the observations in the south and tropical Pacific, but are still too high in the north Pacific (Fig. 4b). In fact, switching off charged or neutral nucleation entirely does not eliminate the overestimation of the simulated ultrafine aerosol concentrations relative to the observations, indicating a general bias of the model that is independent of the nucleation scheme.

Consequently, while the reasons discussed so far may contribute to the observed discrepancy, they do not to explain it, and other model components are likely responsible for the 

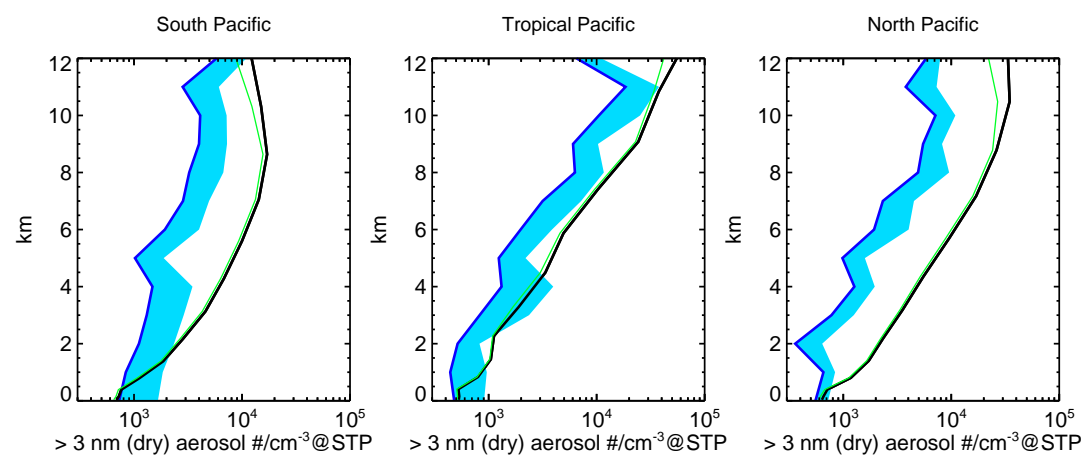

a

- ECHAM5-HAM, $S_{\text {ret }}$

- ECHAM5-HAM, $\mathrm{S}_{\text {ret }}, \mathrm{H}_{2} \mathrm{SO}_{4} / \mathrm{H}_{2} \mathrm{O}$ cluster stability reduced by $1 \mathrm{kcal} / \mathrm{mol}$

South Pacific Tropical Pacific
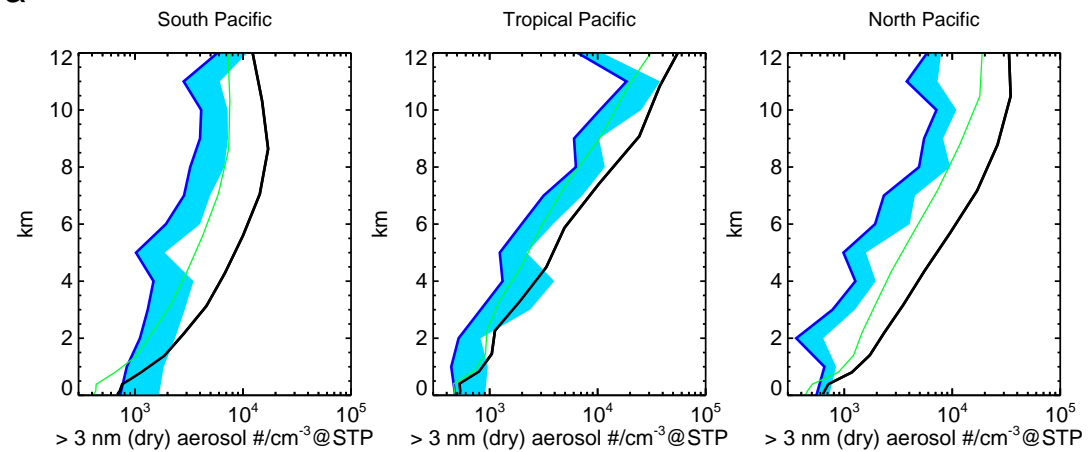

- ECHAM5-HAM, $S$

- ECHAM5-HAM, $\mathrm{S}_{\text {ret }}$, neutral and charged nucleation of $\mathrm{H}_{2} \mathrm{SO}_{4} / \mathrm{H}_{2} \mathrm{O}$ reduced by factor of 0.

b

South Pacific

Tropical Pacific

North Pacific
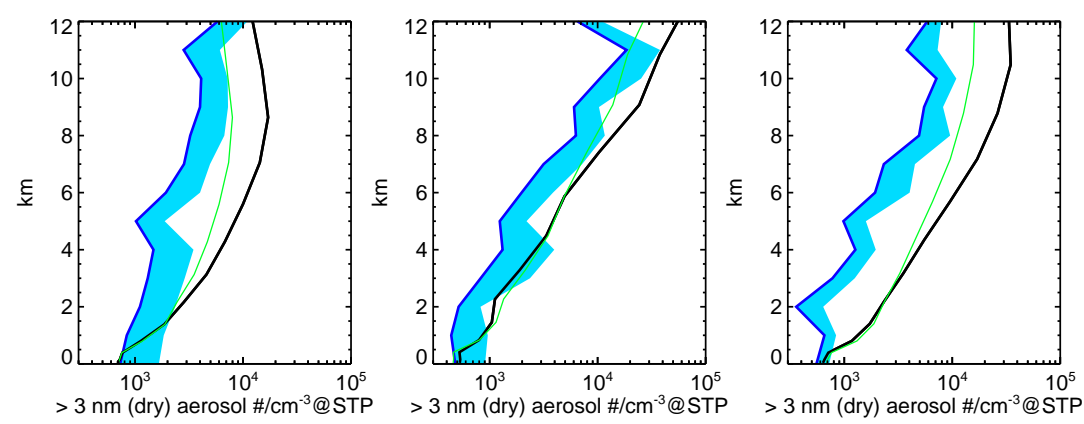

- ECHAM5-HAM, $S_{\text {ret, }}$ max nuc. mode geom. dia. $=10 \mathrm{~nm}$ - Clarke and Kapstin (2002) +

Fig. 4. Comparison of annual mean ultrafine aerosol concentrations from simulation $\mathcal{S}_{\text {ref }}$ (black) with modifications (green) in three regions of

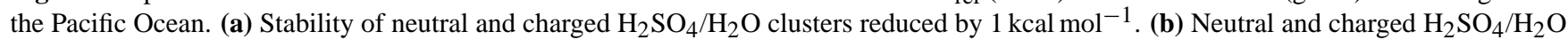
particle formation rates reduced by a factor of 0.1. (c) Maximum geometric mean diameter for the nucleation mode in the $\mathrm{M} 7$ aerosol microphysics module reduced from 10 to $5 \mathrm{~nm}$.

overestimation of the ultrafine particle concentrations. We will limit our investigation to one part of the implementation of aerosol processes in the M7 aerosol microphysics module of ECHAM5-HAM: the ranges in which the geometric mean diameters of the M7 aerosol modes are allowed move. In the default setup, the maximum geometric mean diameter for the nucleation mode is $10 \mathrm{~nm}$. We have repeated simulation $\mathcal{S}_{\text {ref }}$ with this maximum value reduced to $5 \mathrm{~nm}$. This brings the ultrafine aerosol concentrations into much better agreement with the observations in the south and central $\mathrm{Pa}-$ cific, with a less pronounced effect in the north (Fig. 4c). This model parameter has therefore a much stronger effect on the results than possible errors in the physical/chemical processes discussed so far, nearly as much as a reduction of the particle formation rates to $1 / 10$ of their original values (Fig. 4b). Observations show a pronounced gap at $10 \mathrm{~nm}$ in 

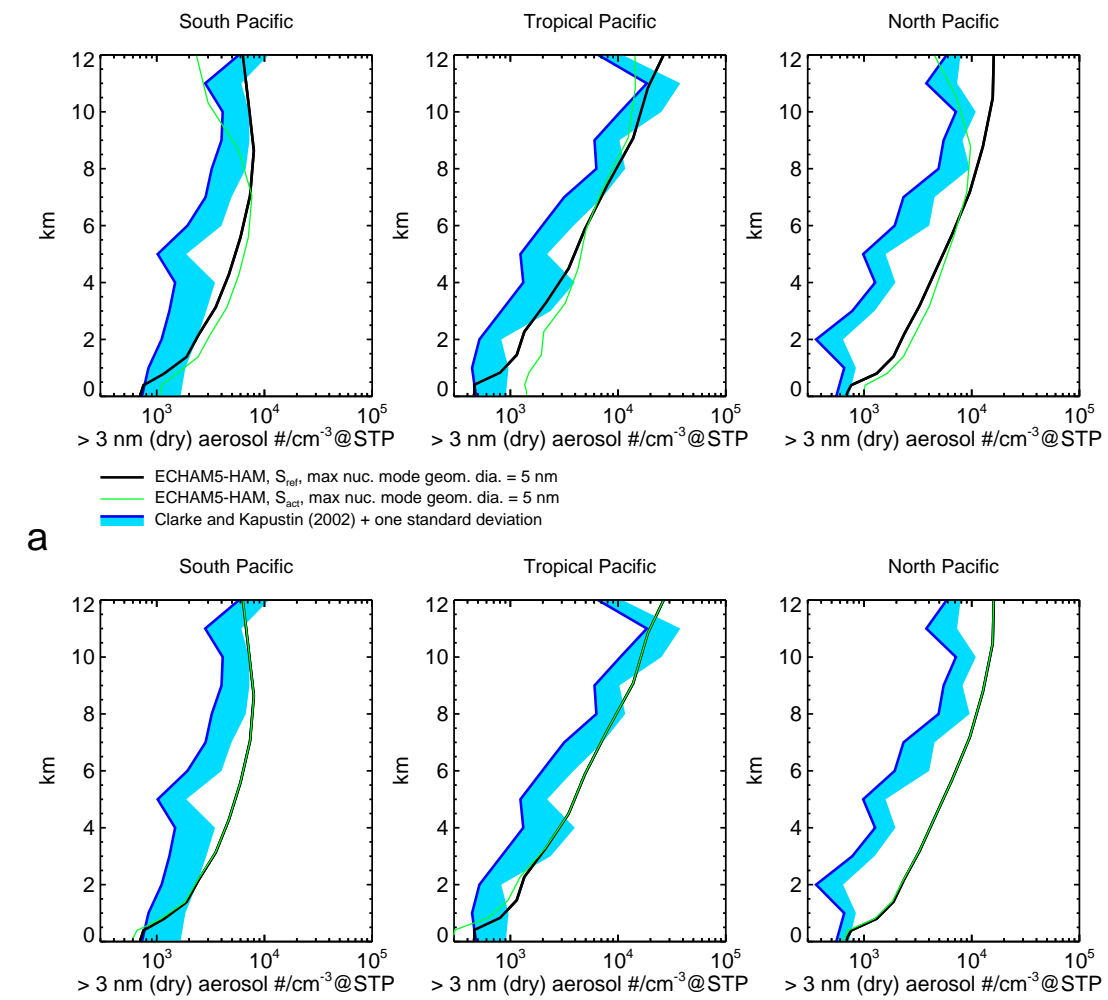

ECHAM5-HAM, $\mathrm{S}_{\text {ret, }}$ max nuc. mode geom. dia. $=5 \mathrm{~nm}$
$\mathrm{ECHAM} 5-\mathrm{HAM}, \mathrm{S}_{\text {naat, }}$ max nuc. mode geom. dia. $=5 \mathrm{~nm}$
Clarke and Kapustin (2002) + one standard deviation

Fig. 5. Comparison of annual mean ultrafine aerosol concentrations from different simulations with observations in three regions of the Pacific Ocean: (a) $\mathcal{S}_{\text {ref }}$ (black), simulation $\mathcal{S}_{\text {act }}$ (green). (b) $\mathcal{S}_{\text {ref }}$ (black), simulation $\mathcal{S}_{\text {noact }}$ (green). A maximum geometric mean diameter of $5 \mathrm{~nm}$ for the nucleation mode in the M7 aerosol microphysics module was used here.

the size distributions of marine ultrafine aerosol (Fig. 6 in Froyd et al., 2009), which suggests that the reduced value is more appropriate. We therefore use in the following $5 \mathrm{~nm}$ as the maximum geometric mean diameter for the nucleation mode.

\subsection{Cluster activation}

Figure 5a compares simulation $\mathcal{S}_{\text {act }}$, where cluster activation is the only nucleation mechanism throughout the model domain, and the reference simulation $\mathcal{S}_{\text {ref }}$, where neutral and charged nucleation proceed throughout the model domain, and cluster activation in the forested boundary layer only, with the Clarke and Kapustin (2002) observations. In the lower troposphere, $\mathcal{S}_{\text {act }}$ shows a higher bias towards high values compared to $\mathcal{S}_{\text {ref }}$, and in particular overestimates ultrafine aerosol concentrations near the surface of the tropical Pacific, where low nucleation rates would be expected due to the warm local temperatures. On the other hand, the ultrafine aerosol concentrations in $\mathcal{S}_{\text {act }}$ decline with altitude in the south and north Pacific upper troposphere, where low temperatures favor a very efficient neutral nucleation of sulfuric acid and water, and thereby higher ultrafine aerosol con- centrations, seen in $\mathcal{S}_{\text {ref }}$ and in the observations. The vertical gradient in the ultrafine aerosol concentrations in $\mathcal{S}_{\text {act }}$ therefore exhibits distinctly different characteristics compared with the vertical gradient in the observations. Interestingly, when nucleation from cluster activation is switched off entirely $\left(\mathcal{S}_{\text {noact }}\right)$, near-surface aerosol concentrations in the south and tropical Pacific are underestimated, while in the original simulation $\mathcal{S}_{\text {ref }}$, where cluster activation proceeds in the forested boundary layer, they agree well with the observations (Fig. 5b). This suggests that aerosol nucleation in the forested boundary layer and subsequent transport of the aerosol particles over the oceans contributes to near-surface marine boundary layer aerosol concentrations, a finding that invites future investigation.

Overall, neutral and charged $\mathrm{H}_{2} \mathrm{SO}_{4} / \mathrm{H}_{2} \mathrm{O}$ nucleation, together with nucleation due to cluster activation in the forested boundary layer produce, despite a general positive bias, ultrafine aerosol concentrations that are more consistent with observations over the ocean than cluster activation as the sole nucleation mechanism throughout the troposphere. 
Ultrafine aerosol in the PBL

(contribution of charged $\mathrm{H}_{2} \mathrm{SO}_{4} / \mathrm{H}_{2} \mathrm{O}$ nucleation in \%)

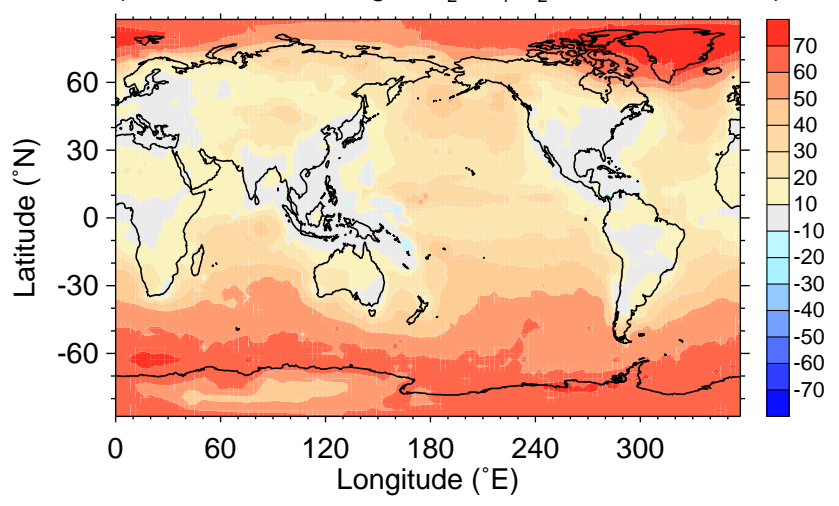

Fig. 6. Contribution of charged $\mathrm{H}_{2} \mathrm{SO}_{4} / \mathrm{H}_{2} \mathrm{O}$ nucleation in simulation $\mathcal{S}_{\text {ref }}$ to the annual mean concentration of ultrafine aerosol (particles with $>3 \mathrm{~nm}$ dry diameter) in the planetary boundary layer.

\subsection{Charged nucleation of sulfuric acid and water}

Figure 6 shows the contribution (defined in Table 3) of charged $\mathrm{H}_{2} \mathrm{SO}_{4} / \mathrm{H}_{2} \mathrm{O}$ nucleation to the concentration of ultrafine aerosol (particles with dry diameter $>3 \mathrm{~nm}$ ) in the planetary boundary layer. The contribution is most significant over the oceans, in particular at mid- and high latitudes, where this process may form locally up to $70 \%$ of the ultrafine aerosol, assisted by cold temperatures and higher ionization rates in these regions. Conversely, at tropical latitudes over the oceans the contribution to the particle concentrations is smaller due to warmer temperatures and lower ionization rates. Over most of the continents, the contribution of charged nucleation of sulfuric acid and water is comparably small, typically $<20 \%$, as here, particles form efficiently via cluster activation. Over southern Finland, we find that charged nucleation of sulfuric acid and water contributes on average less than $10 \%$ to the ultrafine aerosol concentration (Fig. 6). This is in good agreement with measurements in Hyytiälä in southern Finland, where Gagné et al. (2008) found a median contribution of $6.4 \%$ to particles $>2 \mathrm{~nm}$ in size from charged nucleation during one year of measurements. Contributions of a similar magnitude were obtained by Boy et al. (2008) in a modeling study of the boundary layer, who found that charged nucleation of sulfuric acid and water contributes between 0.5 to $12 \%$ to the total amount of newly formed particles inside the mixed layer in Hyytiälä. Yu and Turco (2008) on the other hand explained a majority of nucleation events at the Hyytiälä site with ion-mediated nucleation in a detailed modeling study.

\subsection{Cloud droplet burden}

We use the cloud droplet burden (CDB) from a long term time series (1997-2002) of low-level cloud observations at a continental site $\left(36.6^{\circ} \mathrm{N}, 262.5^{\circ} \mathrm{E}\right)$ (Dong et al., 2005), and from a compilation of marine low-level cloud measurements at various locations (Miles et al., 2000) for evaluation of the model. While the data possibly undersample the continental and marine cloud droplet populations, and due to their focus on low-level clouds may not fully cover their vertical extent, they represent a benchmark for a first assessment of cloud droplet concentrations in the model. Table 5 compares the model annual mean $\mathrm{CDB}$ at $36.6^{\circ} \mathrm{N}, 262.5^{\circ} \mathrm{E}$ with the mean $\mathrm{CDB}$ at the continental location, and the model annual mean CDB over oceans with the mean observed marine CDB.

In the reference simulation $\left(\mathcal{S}_{\text {ref }}\right)$, where neutral and charged nucleation of $\mathrm{H}_{2} \mathrm{SO}_{4}$ and $\mathrm{H}_{2} \mathrm{O}$ proceed throughout the troposphere, and cluster activation in the forested boundary layer only, the simulated continental CDB is in very good agreement with the observations. The model overestimates marine $\mathrm{CDB}$, however. In order to determine whether nucleation is responsible for the high CDB of marine clouds in the model, we compare results from simulation $\mathcal{S}_{0}$, where all nucleation processes are switched off, with the observations. The positive bias in marine CDB is reduced in simulation $\mathcal{S}_{0}$, but still exceeds one sample standard deviation; the continental CDB on the other hand is underestimated. This indicates that aerosol nucleation can at most explain a part of the positive bias in the marine $\mathrm{CDB}$, while the contribution from another model component to the bias is required.

Nucleation from cluster activation does not reproduce the observations as well: in simulation $\mathcal{S}_{\text {act }}$, where cluster activation is the sole nucleation mechanism in the troposphere, both continental and marine CDB exhibit a higher positive bias compared to the reference simulation $\mathcal{S}_{\text {ref }}$, where cluster activation proceeds in the forested boundary layer only, and neutral and charged nucleation of sulfuric acid everywhere (Table 5).

The model results discussed here were obtained with a maximum geometric mean diameter of $5 \mathrm{~nm}$ for the nucleation mode in ECHAM5-HAM, as introduced in Sect. 4.1. For reference, we compare them with results from simulation $\mathcal{S}_{\text {ref }}$ where a maximum value of $10 \mathrm{~nm}$ was used (Table 5). The model substantially overestimates both continental and marine CDBs in this case. The better agreement obtained with the reduced maximum geometric mean diameter supports its use in ECHAM5-HAM, as suggested in Sect. 4.1.

To summarize, we find that neutral and charged nucleation of $\mathrm{H}_{2} \mathrm{SO}_{4}$ and $\mathrm{H}_{2} \mathrm{O}$ throughout the troposphere, and cluster activation limited to the forested boundary layer produce CDBs that agree well with observations at a continental site, while overestimating marine CDBs due to a model bias that cannot be explained with nucleation only. Cluster activation as the sole nucleation mechanism in the troposphere is less compatible with observed cloud droplet burdens than neutral and charged nucleation of $\mathrm{H}_{2} \mathrm{SO}_{4}$ and $\mathrm{H}_{2} \mathrm{O}$ throughout the troposphere, with cluster activation limited to the forested boundary layer. 
Table 5. Comparison of simulated annual mean cloud droplet burdens (in $10^{10} \mathrm{~m}^{-2}$ ), with 5 or 10 nm maximum geometric mean diameter for the nucleation mode, with observations. Sample standard deviations calculated from the data in the referenced sources are given in brackets.

\begin{tabular}{|c|c|c|c|c|c|c|}
\hline Observations & & $\begin{array}{c}\mathcal{S}_{\mathrm{ref}} \\
(5 \mathrm{~nm})\end{array}$ & $\begin{array}{c}\mathcal{S}_{0} \\
(5 \mathrm{~nm})\end{array}$ & $\begin{array}{c}\mathcal{S}_{\mathrm{act}} \\
(5 \mathrm{~nm})\end{array}$ & $\begin{array}{c}\mathcal{S}_{\text {ref }} \\
(10 \mathrm{~nm})\end{array}$ & Model location \\
\hline $\begin{array}{l}\text { Dong et al. (2005), } \\
1997-2002 \text { average } \\
\text { at a continental site } \\
\left(36.6^{\circ} \mathrm{N}, 262.5^{\circ} \mathrm{E}\right) \\
\text { daytime } \\
\text { nighttime }\end{array}$ & $\begin{array}{l}18.1(16.0) \\
17.4(15.5)\end{array}$ & 19.0 & 7.4 & 22.4 & 30.0 & $36.6^{\circ} \mathrm{N}, 262.5^{\circ} \mathrm{E}$ \\
\hline $\begin{array}{l}\text { Miles et al. (2000), } \\
\text { marine low-level } \\
\text { stratiform clouds } \\
\text { at various locations }\end{array}$ & $2.6(1.6)$ & 6.1 & 4.5 & 6.5 & 7.2 & Ocean average \\
\hline
\end{tabular}

\subsection{Individual nucleation processes, aerosol, clouds and radiation}

Here we examine, using the approach described in Sect. 3, how the nucleation mechanisms considered in the model affect aerosol concentrations, clouds, and the Earth's radiative forcing on an annual mean basis. For reference in the following discussion, the annual and zonal mean concentrations of particles in the nucleation, Aitken, and accumulation mode in simulation $\mathcal{S}_{\text {ref }}$ are given in Fig. 7.

Figure 8 shows the vertical and meridional structure of the charged $\mathrm{H}_{2} \mathrm{SO}_{4} / \mathrm{H}_{2} \mathrm{O}$ nucleation contribution to particle concentrations in the nucleation, Aitken, and accumulation mode in simulation $\mathcal{S}_{\text {ref. }}$ The contribution is strongest in the nucleation mode (Fig. 8a), where charged nucleation contributes the majority of particles below $300 \mathrm{hPa}$, except in the tropical and sub-tropical lower troposphere, where an efficient formation of particles from cluster activation takes place, discussed below. The negative contributions seen in the tropical and sub-tropical lower troposphere in Fig. 8a are likely due to feedback effects in the model. Above $300 \mathrm{hPa}$, the contribution of charged nucleation is strongly suppressed as neutral nucleation of $\mathrm{H}_{2} \mathrm{SO}_{4} / \mathrm{H}_{2} \mathrm{O}$ becomes efficient due to its highly non-linear increase with decreasing temperatures.

In the Aitken mode, charged nucleation contributes most in the lower troposphere outside of the tropics (Fig. 8b), where up to $50 \%$ of the Aitken mode particles form due to charged nucleation. Interestingly, in the same regions the contribution of charged nucleation to the accumulation mode is negative (Fig. 8c). We explain this by a slower growth of Aitken mode particles into the accumulation mode when charged nucleation contributes to particle formation, as sulfate needed for growth is distributed onto more particles. Charged nucleation contributes only very little to coarse mode concentrations (not shown), as these particles originate largely from surface emissions (sea salt and dust).
Figure 9 shows the vertical and meridional structure of the contribution of cluster activation to particle concentrations in the nucleation, Aitken, and accumulation mode in simulation $\mathcal{S}_{\text {ref. This process contributes most strongly to the nucleation }}$ (with up to 90\%) and Aitken mode (with up to 50\%) in the tropical and sub-tropical lower troposphere (Fig. 9a and b), where it exceeds the contribution from charged nucleation to these modes (Fig. 8a and b). The contribution of cluster activation to the accumulation mode is strongest in the lower troposphere of the northern hemisphere (Fig. 9c), with values between 1 and $5 \%$ in the zonal mean. The contribution of nucleation due to cluster activation to coarse mode particle concentrations is small, and not shown here.

Aerosol particles in the ECHAM5-HAM model are activated and may become cloud droplets (Lohmann et al., 2007). The number and size of cloud droplets determine the radiative properties of the cloud: clouds with more but smaller cloud droplets, which formed at higher aerosol concentrations, have a higher albedo and reflect more incoming solar radiation into space at a fixed liquid water path (Twomey, 1977), thus reducing the net top-of-theatmosphere short-wave radiation (TOASW), which is equivalent to the total absorbed solar short-wave radiation. Using the definition in Table 3, we quantify the contribution of the different aerosol nucleation processes to cloud properties and TOASW.

Figure 10 shows the individual and combined contributions of the three aerosol nucleation mechanisms considered in this work to the cloud drop burden. Charged nucleation of $\mathrm{H}_{2} \mathrm{SO}_{4} / \mathrm{H}_{2} \mathrm{O}$ contributes more strongly to the cloud drop burden over the oceans than over continents, in particular in the southern hemisphere, with peak values between 15-20\% (Fig. 10a). The weaker contributions over the continents are likely due to competition with cluster activation and primary emissions. Cluster activation on the other hand contributes more strongly over continental regions, where forests occur, 
Nucleation mode concentration $\left(\mathrm{cm}^{-3}\right)$

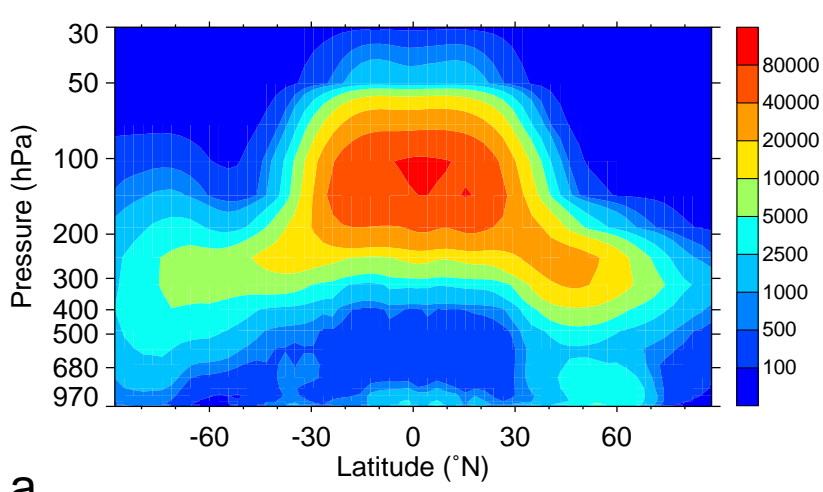

Aitken mode concentration $\left(\mathrm{cm}^{-3}\right)$

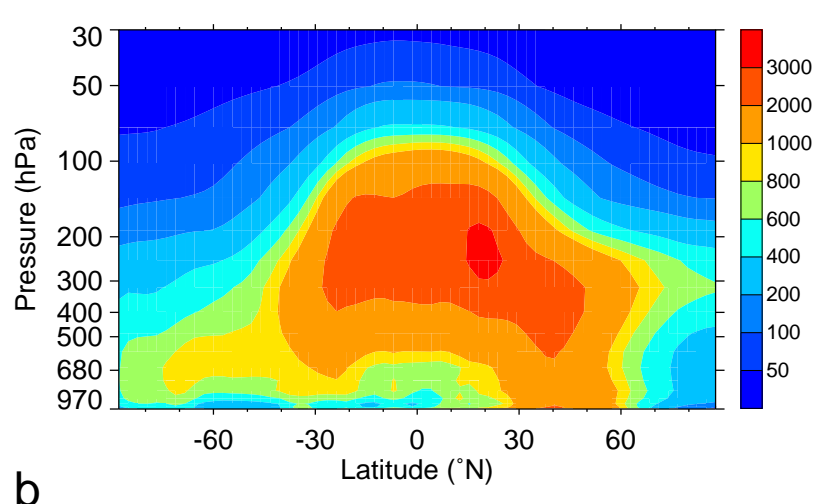

Accumulation mode concentration $\left(\mathrm{cm}^{-3}\right)$

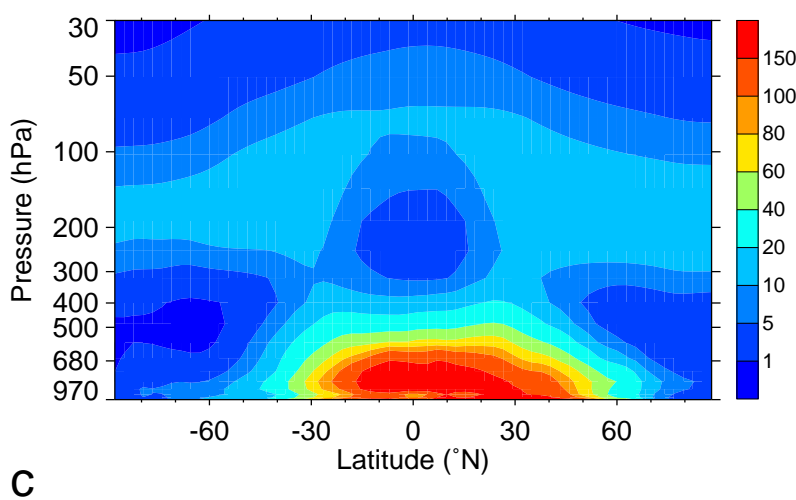

Fig. 7. Annual and zonal mean concentrations (in ambient conditions) of (a) nucleation, (b) Aitken, and (c) accumulation mode particles in simulation $\mathcal{S}_{\text {ref }}$.

and downwind thereof, with peak values between $15-20 \%$, but its impact is weaker over the open oceans (Fig. 10b). The contribution of neutral nucleation of $\mathrm{H}_{2} \mathrm{SO}_{4} / \mathrm{H}_{2} \mathrm{O}$ is very small (Fig. 10c), because it proceeds efficiently mainly in the upper troposphere, from where the nucleated particles need to descend to lower altitudes; during this transport they are depleted before being activated. The combined contribution
Nucleation mode concentration

(contribution of charged $\mathrm{H}_{2} \mathrm{SO}_{4} / \mathrm{H}_{2} \mathrm{O}$ nucleation in \%)

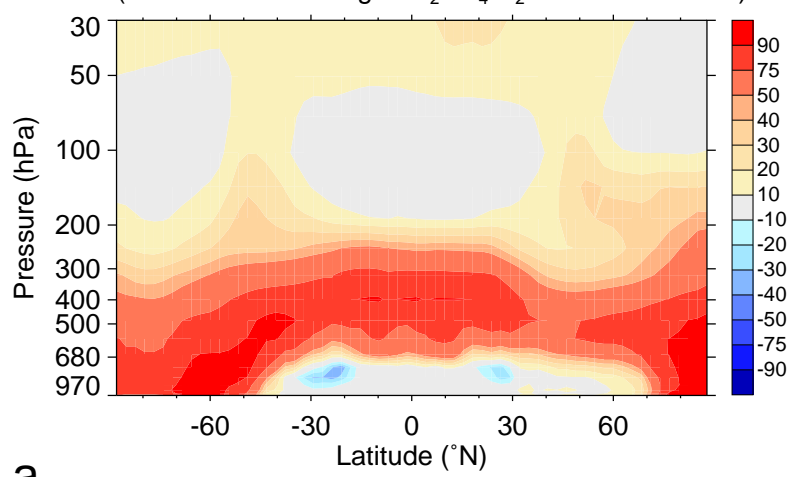

a

Aitken mode concentration

(contribution of charged $\mathrm{H}_{2} \mathrm{SO}_{4} / \mathrm{H}_{2} \mathrm{O}$ nucleation in \%)

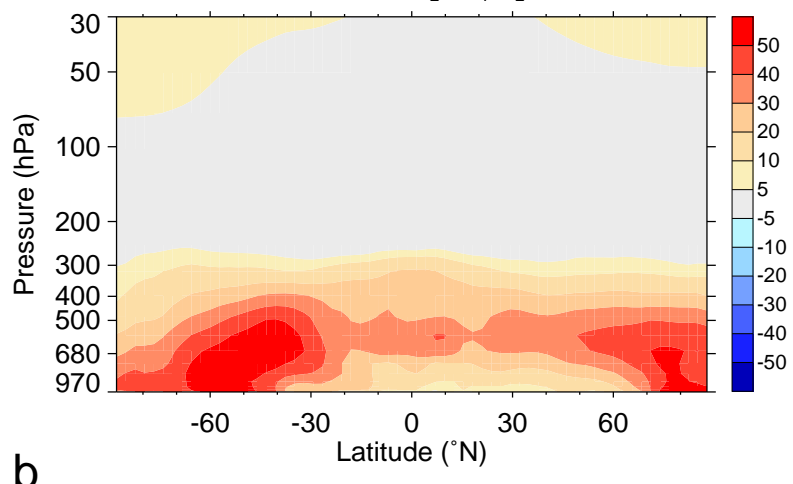

Accumulation mode concentration (contribution of charged $\mathrm{H}_{2} \mathrm{SO}_{4} / \mathrm{H}_{2} \mathrm{O}$ nucleation in \%)

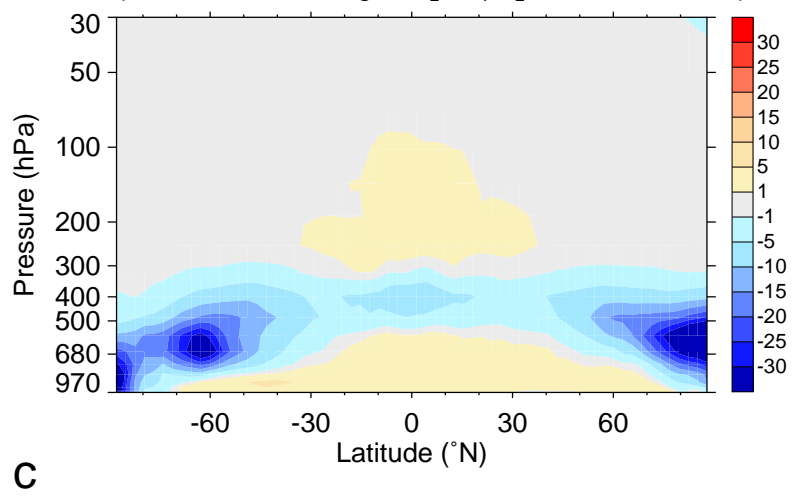

Fig. 8. Contribution of charged $\mathrm{H}_{2} \mathrm{SO}_{4} / \mathrm{H}_{2} \mathrm{O}$ nucleation in simulation $\mathcal{S}_{\text {ref }}$ to the annual and zonal mean concentration of (a) nucleation, (b) Aitken, and (c) accumulation mode particles. The contribution to coarse mode particles (not shown) is very small.

of all nucleation processes in the model is shown in Fig. 10d; over large areas of the globe aerosol nucleation accounts for in excess of $20 \%$ of the cloud droplet burden.

Figure 11 shows the individual and combined contributions of the three aerosol nucleation mechanisms to TOASW. The strongest contribution comes from charged nucleation of sulfuric acid and water, which contributes most strongly over 


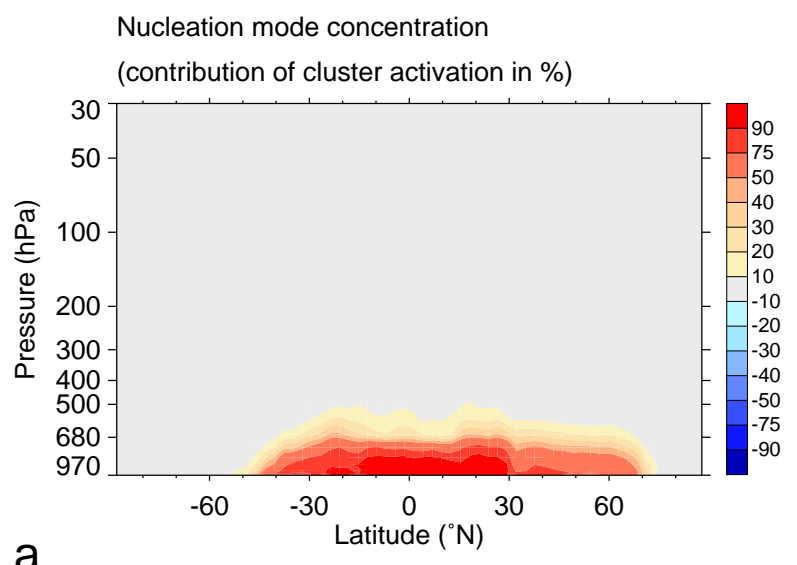

a

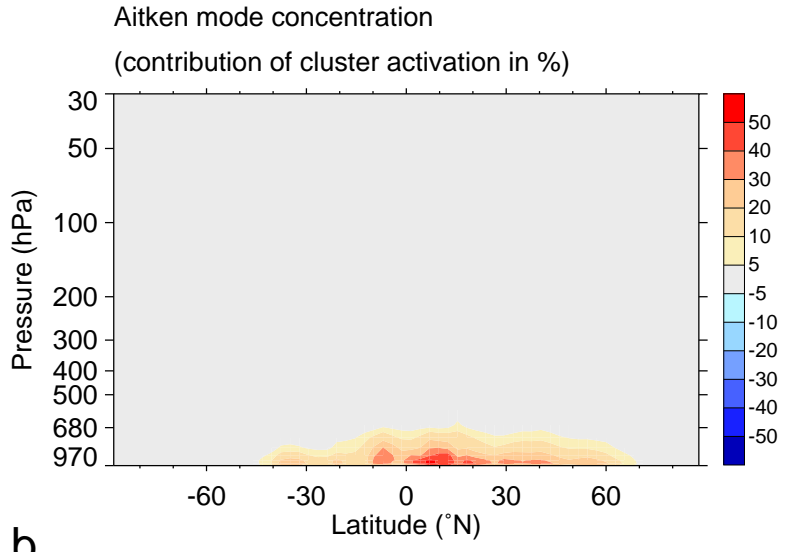

b

Accumulation mode concentration (contribution of cluster activation in \%)

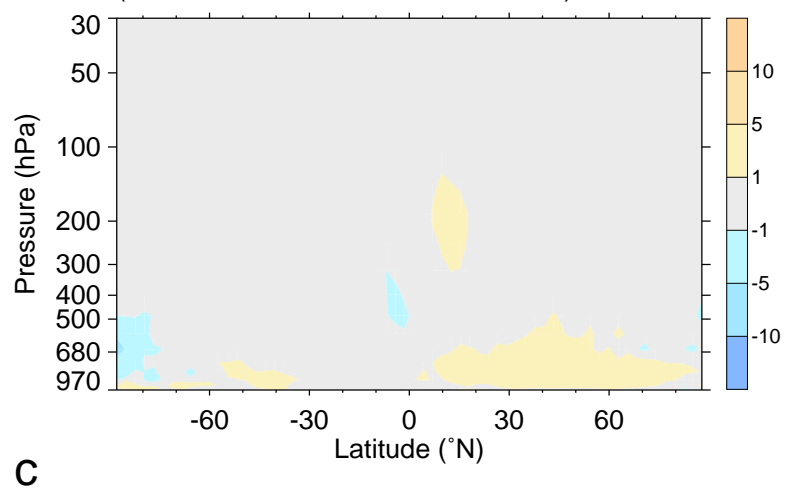

Fig. 9. Contribution of cluster activation in simulation $\mathcal{S}_{\text {ref }}$ to the annual and zonal mean concentration of (a) nucleation, (b) Aitken, and (c) accumulation mode particles. The contribution to coarse mode particles (not shown) is very small.

the oceans, with up to $-4 \mathrm{~W} / \mathrm{m}^{2}$ (Fig. 11a). Cluster activation contributes mainly over and downwind of continents, where aerosol particles that formed in the forested boundary layer are transported (Fig. 11b), with peak values between -1 and $-1.5 \mathrm{~W} / \mathrm{m}^{2}$. The contribution of neutral nucleation of sulfuric acid and water is negligible (Fig. 11c). The contribution of all nucleation processes is dominated by the strong signa- ture of charged nucleation, aided by nucleation from cluster activation (Fig. 11d).

The globally averaged annual mean contributions of the individual processes to TOASW via the direct, semi-direct, indirect cloud-albedo and cloud-lifetime effects are $-1.15 \mathrm{~W} / \mathrm{m}^{2}$ for charged $\mathrm{H}_{2} \mathrm{SO}_{4} / \mathrm{H}_{2} \mathrm{O}$ nucleation, $-0.235 \mathrm{~W} / \mathrm{m}^{2}$ for cluster activation in the forested boundary layer, $-0.05 \mathrm{~W} / \mathrm{m}^{2}$ for neutral $\mathrm{H}_{2} \mathrm{SO}_{4} / \mathrm{H}_{2} \mathrm{O}$ nucleation, and $-2.55 \mathrm{~W} / \mathrm{m}^{2}$ for their combined effect, which exceeds the sum of the individual terms due to feedbacks and interactions in the model. Over the oceans, aerosol nucleation has a larger impact on Earth's radiative forcing, with a contribution of $-2.18 \mathrm{~W} / \mathrm{m}^{2}$ to TOASW, compared to land with a contribution of $-0.37 \mathrm{~W} / \mathrm{m}^{2}$.

The general high bias in ultrafine aerosol concentrations in the model may lead to an overestimation of the fraction of cloud droplets that have formed from aerosol nucleation. This in turn may result in an overestimation of the contribution of aerosol nucleation to net TOASW. The model results are subject to other uncertainties, e.g. due to the limited spatial and temporal resolution of the model: global models do, e.g., generally not represent the vertical temperature profile with a resolution that is sufficient to accurately reproduce boundary layer clouds. In particular, this may lead to errors in mixing between the boundary layer and the free troposphere, which affects cloud properties. Another uncertainty is imposed on our results by the specific aerosol activation scheme used. We used the parametrization of Lin and Leaitch (1997), as in Lohmann et al. (2007). Other activation schemes, such as the parametrization by Abdul-Razzak and Ghan (2000), need not produce identical results. The sensitivity of the role of aerosol nucleation for radiative forcing to the aerosol activation scheme used will be investigated.

\section{Conclusions}

Three aerosol nucleation mechanisms, described based on laboratory or field measurements, were incorporated into the aerosol-climate model ECHAM5-HAM: neutral and charged nucleation of $\mathrm{H}_{2} \mathrm{SO}_{4}$ and $\mathrm{H}_{2} \mathrm{O}$, and nucleation of an organic compound and sulfuric acid via cluster activation. In a series of simulations, ultrafine aerosol concentrations and cloud droplet burdens were compared with observations, and the role of the individual aerosol nucleation processes for clouds and the Earth's radiative forcing was investigated.

We find that despite a general high bias of ultrafine aerosol concentrations in the model, neutral and charged nucleation of $\mathrm{H}_{2} \mathrm{SO}_{4}$ and $\mathrm{H}_{2} \mathrm{O}$ proceeding throughout the troposphere, and cluster activation limited to the forested boundary layer give ultrafine aerosol concentrations and cloud droplet burdens that are more consistent with observations than cluster activation as the sole nucleation mechanism throughout the troposphere. This finding can be explained with the consideration that organic molecules, such as emitted by trees, 

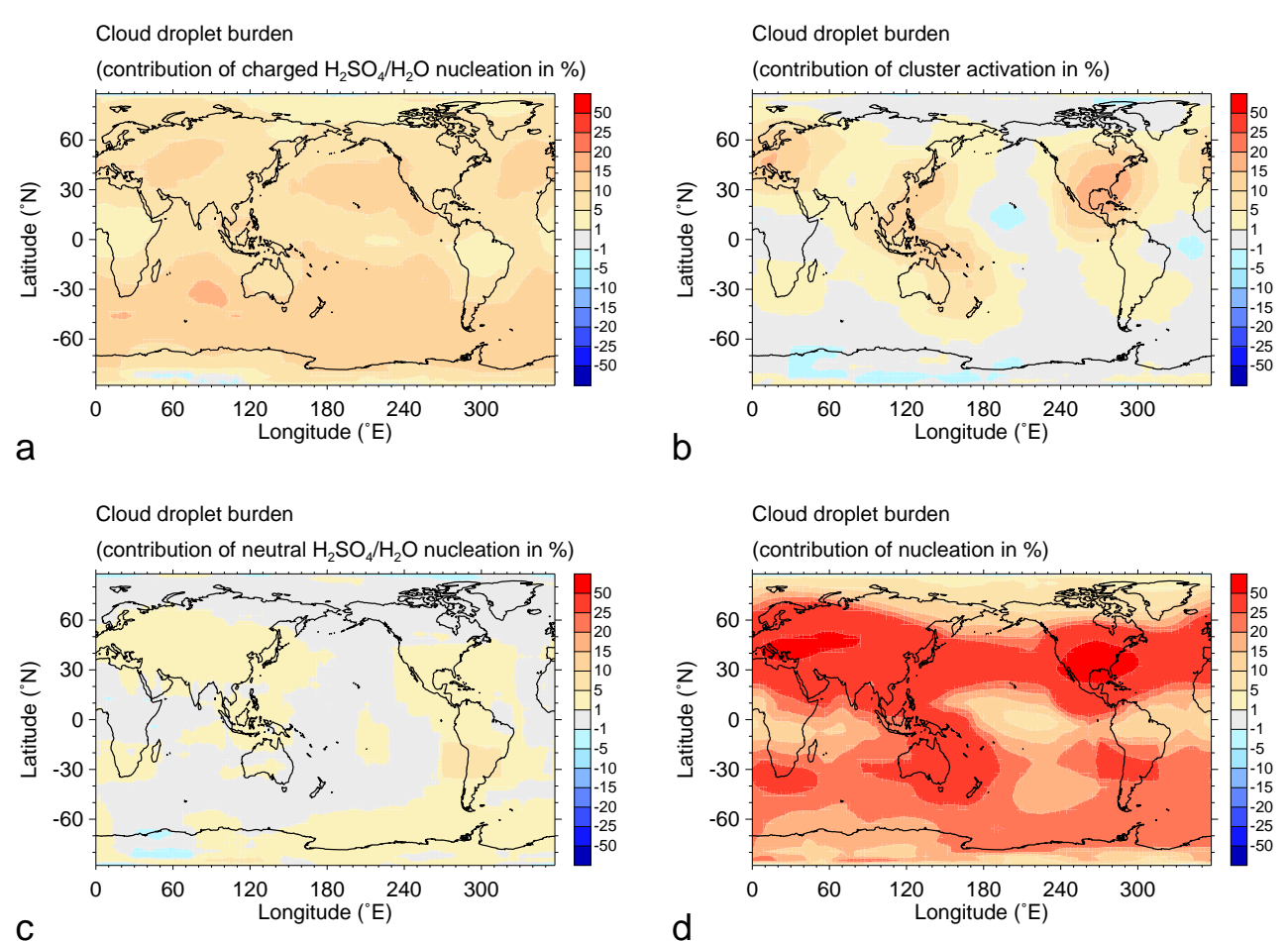

Fig. 10. Contribution of (a) charged $\mathrm{H}_{2} \mathrm{SO}_{4} / \mathrm{H}_{2} \mathrm{O}$ nucleation, (b) cluster activation, (c) neutral $\mathrm{H}_{2} \mathrm{SO}_{4} / \mathrm{H}_{2} \mathrm{O}$ nucleation, and (d) all nucleation in simulation $\mathcal{S}_{\text {ref }}$ to the annual mean cloud drop burden. The data were smoothed using a box-shaped, area-weighted low-pass filter covering four latitude and eight longitude points.

which are responsible for nucleation due to cluster activation, are typically found in highest concentrations in the boundary layer over forests. While we do not exclude the possibility that cluster activation, and more generally nucleation involving organics do proceed over the oceans and in the free troposphere, it is plausible that owing to the lower concentrations of organic molecules, they proceed there at lower rates than observed in the forested boundary layer. Consequently, at locations with low concentrations of organic molecules, other nucleation mechanisms, including neutral and charged nucleation of sulfuric acid may play a more important role.

In our model study, charged nucleation of sulfuric acid and water exceeds cluster activation and neutral nucleation of sulfuric acid and water in terms of relevance for cloud properties and Earth's radiative forcing: in the global mean, charged nucleation contributes to net top-of-the-atmosphere shortwave radiation with $-1.15 \mathrm{~W} / \mathrm{m}^{2}$. Cluster activation in the forested boundary layer contributes $-0.235 \mathrm{~W} / \mathrm{m}^{2}$ globally, although its contribution to ultrafine aerosol concentrations and cloud drop concentrations over continental areas and downwind thereof is higher than the contribution of charged nucleation. The large effect of charged nucleation is not in contradiction with small effects seen in local measurements: over southern Finland, where nucleation via cluster activation proceeds efficiently, we find that charged nucleation of sulfuric acid and water contributes on average less than $10 \%$ to ultrafine aerosol concentrations, in good agreement with observations. Neutral nucleation of sulfuric acid and water plays the least important role of the three aerosol nucleation mechanisms, and its contribution to net top-ofthe-atmosphere shortwave radiation is very small. The globally averaged annual mean contribution of aerosol nucleation to net top-of-the-atmosphere shortwave radiation via the direct, semi-direct, indirect cloud-albedo and cloud-lifetime effects is $-2.55 \mathrm{~W} / \mathrm{m}^{2}$ in our simulations, which exceeds the sum of the contributions of the individual nucleation mechanisms due to feedbacks and interactions in the model.

Finally, we find that aerosol nucleation plays a more important role for Earth's radiative forcing over the oceans than over land, with a contribution of $-2.18 \mathrm{~W} / \mathrm{m}^{2}$ to net topof-the-atmosphere short-wave radiation over oceans, compared to a contribution of $-0.37 \mathrm{~W} / \mathrm{m}^{2}$ over land. We explain the higher effect of aerosol nucleation on Earth's radiative forcing over the oceans with the larger area covered by ocean clouds, due to the larger contrast in albedo between clouds and the ocean surface compared to continents, and the larger susceptibility of pristine clouds owing to the saturation of effects. 

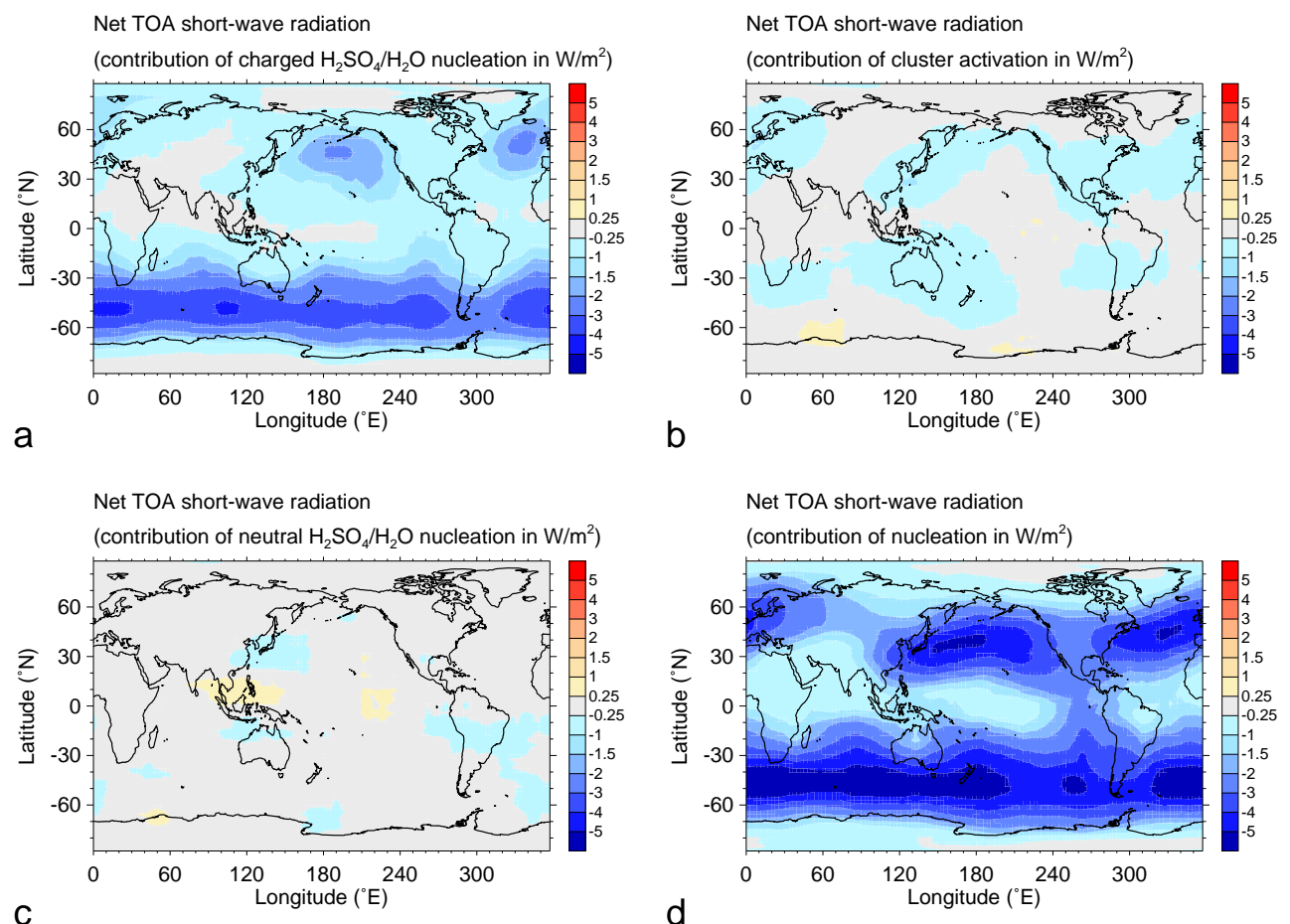

Fig. 11. Contribution of (a) charged $\mathrm{H}_{2} \mathrm{SO}_{4} / \mathrm{H}_{2} \mathrm{O}$ nucleation, (b) cluster activation, (c) neutral $\mathrm{H}_{2} \mathrm{SO}_{4} / \mathrm{H}_{2} \mathrm{O}$ nucleation, and (d) all nucleation in simulation $\mathcal{S}_{\text {ref }}$ to the annual mean net top-of-the-atmosphere short-wave radiation. The data were smoothed using a box-shaped, areaweighted low-pass filter covering four latitude and eight longitude points.

Acknowledgements. We thank K. O'Brien (Northern Arizona University) for providing data of atmospheric ionization by galactic cosmic rays, N. A. Tsyganenko (Saint Petersburg State University) for providing the GEOPACK 2005 code, C. Timmreck (Max Planck Institute for Meteorology) for carefully reviewing the manuscript, and M. Wang (Pacific Northwest National Laboratory) for helpful comments. The first author thanks K. D. Froyd (NOAA Earth System Research Laboratory) for helpful discussions. This work has been partly funded by the European Integrated Project on Aerosol-Cloud-Climate and Air Quality Interactions (EUCAARI) No 036833-2.

The service charges for this open access publication have been covered by the Max Planck Society.

Edited by: K. Carslaw

\section{References}

Abdul-Razzak, H. and Ghan, S. J.: A parameterization of aerosol activation 2. Multiple aerosol types, J. Geophys. Res., 105, 6837-6844, 2000.

Albrecht, B. A.: Aerosols, cloud microphysics and fractional cloudiness, Science, 245, 1227-1230, 1989.

Ball, S. M., Hanson, D. R., Eisele, F. L., and McMurry, P. H.: Laboratory studies of particle nucleation: initial results for $\mathrm{H}_{2} \mathrm{SO}_{4}$, $\mathrm{H}_{2} \mathrm{O}$, and $\mathrm{NH}_{3}$ vapors. J. Geophys. Res., 104, 23709-23718, 1999.
Birmili, W., Berresheim, H., Plass-Dülmer, C., Elste, T., Gilge, S., Wiedensohler, A., and Uhrner, U.: The Hohenpeissenberg aerosol formation experiment (HAFEX): a longterm study including size-resolved aerosol, $\mathrm{H} 2 \mathrm{SO} 4, \mathrm{OH}$, and monoterpenes measurements, Atmos. Chem. Phys., 3, 361-376, doi:10.5194/acp-3-361-2003, 2003.

Boy, M., Kazil, J., Lovejoy, E. R., Guenther, A., and Kulmala, M.: Relevance of ion-induced nucleation of sulfuric acid and water in the lower troposphere over the boreal forest at northern latitudes, Atmos. Res., 90(2-4), 151-158, 2008.

Brock, C. A., Hamill, P., Wilson, J. C., Jonsson, H. H., and Chan, K. R.: Particle formation in the upper tropical troposphere: a source of nuclei for the stratospheric aerosol. Science, 270, 1650-1653, 1995.

Burkholder, J. B., Baynard, T., Ravishankara, A. R., and Lovejoy, E. R.: Particle nucleation following the $\mathrm{O}_{3}$ and $\mathrm{OH}$ initiated oxidation of $\alpha$-pinene and $\beta$-pinene between 278 and $320 \mathrm{~K}$, J. Geophys. Res., 112, D10216, doi:10.1029/2006JD007783, 2007.

Burkholder, J. B., Curtius, J., Ravishankara, A. R., and Lovejoy, E. R.: Laboratory studies of the homogeneous nucleation of iodine oxides, Atmos. Chem. Phys., 4, 19-34, doi:10.5194/acp-4-192004, 2004.

Clarke, A. D. and Kapustin, V. N.: A Pacific aerosol survey. part I: A decade of data on particle production, transport, evolution, and mixing in the troposphere. J. Atmos. Sci., 52, 363-382, 2002.

Coffman, D. J. and Hegg, D. A.: A preliminary study of the effect of ammonia on particle nucleation in the marine boundary layer, J. Geophys. Res., 100(D4), 7147-7160, 1995.

Curtius, J., Froyd, K. D., and Lovejoy, E. R.: Cluster ion thermal 
decomposition (I): Experimental kinetics study and ab initio calculations for $\mathrm{HSO}_{4}^{-}\left(\mathrm{H}_{2} \mathrm{SO}_{4}\right)_{(\mathrm{x})}\left(\mathrm{HNO}_{3}\right)_{(\mathrm{y})}$, J. Phys. Chem. A., 105(48), 10867-10873, 2001.

Dentener, F., Kinne, S., Bond, T., Boucher, O., Cofala, J., Generoso, S., Ginoux, P., Gong, S., Hoelzemann, J. J., Ito, A., Marelli, L., Penner, J. E., Putaud, J.-P., Textor, C., Schulz, M., van der Werf, G. R., and Wilson, J.: Emissions of primary aerosol and precursor gases in the years 2000 and 1750 prescribed data-sets for AeroCom, Atmos. Chem. Phys., 6, 4321-4344, doi:10.5194/acp6-4321-2006, 2006.

Dong, X., Minnis, P., and Xi, B.: A climatology of midlatitude continental clouds from the ARM SGP Central Facility: Part i: Lowlevel cloud macrophysical, microphysical, and radiative properties, J. Clim., 18, 1391-1410, 2005.

Eichkorn, S., Wilhelm, S., Aufmhoff, H., Wohlfrom, K. H., and Arnold, F.: Cosmic ray-induced aerosol-formation: First observational evidence from aircraft-based ion mass spectrometer measurements in the upper troposphere, Geophys. Res. Lett., 29, 1698, doi:10.1029/2002GL015044, 2002.

Feichter, J., Kjellström, E., Rodhe, H., Dentener, F., Lelieveld, J., and Roelofs, G.-J.: Simulation of the tropospheric sulfur cycle in a global climate model, Atmos. Environ., 30(10-11), 16931707, 1996.

Forbush, S. E.: Worldwide cosmic ray variations, 1937-1952, J. Geophys. Res., 59, 525-542, 1954.

Froyd, K. D. and Lovejoy, E. R.: Experimental thermodynamics of cluster ions composed of $\mathrm{H}_{2} \mathrm{SO}_{4}$ and $\mathrm{H}_{2} \mathrm{O}$. 2. measurements and $\mathrm{ab}$ initio structures of negative ions, J. Phys. Chem. A., 107(46), 9812-9824, 2003.

Froyd, K. D., Murphy, D. M., Sanford, T. J., Thomson, D. S., Wilson, J. C., Pfister, L., and Lait, L.: Aerosol composition of the tropical upper troposphere, Atmos. Chem. Phys., 9, 4363-4385, doi:10.5194/acp-9-4363-2009, 2009.

Fry, J. L., Kiendler-Scharr, A., Rollins, A. W., Wooldridge, P. J., Brown, S. S., Fuchs, H., Dubé, W., Mensah, A., dal Maso, M., Tillmann, R., Dorn, H.-P., Brauers, T., and Cohen, R. C.: Organic nitrate and secondary organic aerosol yield from $\mathrm{NO}_{3}$ oxidation of $\beta$-pinene evaluated using a gas-phase kinetics/aerosol partitioning model, Atmos. Chem. Phys., 9, 14311449, doi:10.5194/acp-9-1431-2009, 2009.

Fuchs, N. A.: The Mechanics of Aerosols, Pergamon Press, distributed by The Macmillan Company, New York, 288-302, 1964.

Gagné, S., Laakso, L., Petäjä, T., Kerminen, V.-M., and Kulmala, M.: Analysis of one year of Ion-DMPS data from the SMEAR II station, Finland, Tellus B, 60, 318-329, 2008.

Gaydos, T. M., Stanier, C. O., and Pandis, S. N.: Modeling of in situ ultrafine atmospheric particle formation in the eastern United States, J. Geophys. Res., 110, D07S12, 2005.

Gleeson, L. J. and Axford, W. I.: Solar modulation of galactic cosmic rays, Astrophys. J., 154, 1011-1026, 1968.

Hanson, D. R. and Lovejoy, E. R.: Measurement of the thermodynamics of the hydrated dimer and trimer of sulfuric acid, J. Phys. Chem. A., 110(31), 9525-9528, 2006.

Hegg, D. A., Livingston, J. Hobbs, P. V., Novakov, T., and Russell, P.: Chemical apportionment of aerosol column optical depth off the mid-Atlantic coast of the United States, J. Geophys. Res., 102, 25293-25304, 1997.

Heintzenberg, J., Covert, D. S., and Van Dingenen, R.: Size distribution and chemical composition of marine aerosols: A compi- lation and review, Tellus, 52B, 1104-1122, 2000.

Jeuken, A. B. M., Siegmund, P. C., Heijboer, L. C., Feichter, J., and Bengtsson, L.: On the potential of assimilating meteorological analyses in a global climate model for the purpose of model validation, J. Geophys. Res., 101, 16939-16950, 1996.

Jimi, S. I., Siems, S. T., McGregor, J. L., Gras, J. L., and Katzfey, J. J.: An investigation into the origin of aerosol nucleation events observed in the southern ocean boundary layer, Aust. Met. Mag., 57(2), 85-93, 2008.

Jung, J. G., Pandis, S., and Adams, P.: Evaluation of nucleation theories in a sulfur-rich environment, Aer. Sci. Tech., 42(7), 495504, 2008.

Kärcher, B. and Ström, J.: The roles of dynamical variability and aerosols in cirrus cloud formation, Atmos. Chem. Phys., 3, 823838, doi:10.5194/acp-3-823-2003, 2003.

Kazil, J., Harrison, R. G., and Lovejoy, E. R.: Tropospheric new particle formation and the role of ions, Space Sci. Rev., 241-255, 2008.

Kazil, J. and Lovejoy, E. R.: A semi-analytical method for calculating rates of new sulfate aerosol formation from the gas phase, Atmos. Chem. Phys., 7, 3447-3459, doi:10.5194/acp-7-3447-2007, 2007.

Kokkola, H., Hommel, R., Kazil, J., Niemeier, U., Partanen, A., Feichter, J., and Timmreck, C.: Aerosol microphysics modules in the framework of the ECHAM5 climate model - intercomparison under stratospheric conditions, Geosci. Model Dev., 2, 97-112, 2009.

Korhonen, H., Carslaw, K. S., and Romakkaniemi, S.: Enhancement of marine cloud albedo via controlled sea spray injections: a global model study of the influence of emission rates, microphysics and transport, Atmos. Chem. Phys., 10, 4133-4143, doi:10.5194/acp-10-4133-2010, 2010.

Kulmala, M., Lehtinen, K. E. J., and Laaksonen, A.: Cluster activation theory as an explanation of the linear dependence between formation rate of $3 \mathrm{~nm}$ particles and sulphuric acid concentration, Atmos. Chem. Phys., 6, 787-793, doi:10.5194/acp-6-787-2006, 2006.

Kulmala, M., Vehkamäki, H., Petäjä, T., Dal Maso, M., Lauri, A., Kerminen, V.-M., Birmili, W., and McMurry, P. H.: Formation and growth rates of ultrafine atmospheric particles: a review of observations, J. Aer. Sci., 35(2), 143-176, 2004.

Kurtén, T., Loukonen, V., Vehkamki, H., and Kulmala, M.: Amines are likely to enhance neutral and ion-induced sulfuric acid-water nucleation in the atmosphere more effectively than ammonia, Atmos. Chem. Phys., 8, 4095-4103, doi:10.5194/acp-8-4095-2008, 2008.

Lee, S.-H., Reeves, J. M., Wilson, J. C., Hunton, D. E., Viggiano, A. A., Miller, T. M., Ballenthin, J. O., and Lait, L. R.: Particle formation by ion nucleation in the upper troposphere and lower stratosphere, Science, 301, 1886-1889, 2003.

Lin, H. and Leaitch, W. R.: Development of an in-cloud aerosol activation parameterization for climate modelling. Proceedings of the WMO Workshop on Measurement of Cloud Properties for Forecasts of Weather, Air Quality and Climate, Geneva, World Meteorol. Organ, 328-335, 1997.

Lohmann, U. and Roeckner, E.: Design and performance of a new cloud microphysics scheme developed for the ECHAM general circulation model, Clim. Dynam., 12(8), 557-572, 1996.

Lohmann, U., Spichtinger, P., Jess, S., Peter, T., and Smit, H.: Cir- 
rus cloud formation and ice supersaturated regions in a global climate model, Env. Res. Lett., 3(4), 045022, doi:10.1088/17489326/3/4/045022, 2008.

Lohmann, U., Stier, P., Hoose, C., Ferrachat, S., Kloster, S., Roeckner, E., and Zhang, J.: Cloud microphysics and aerosol indirect effects in the global climate model ECHAM5-HAM, Atmos. Chem. Phys., 7, 3425-3446, doi:10.5194/acp-7-3425-2007, 2007.

Lovejoy, E. R., Curtius, J., and Froyd, K. D.: Atmospheric ioninduced nucleation of sulfuric acid and water, J. Geophys. Res., 109, D08204, doi:10.1029/2003JD004460, 2004.

Mäkelä, J. M., Ylikoivisto, S., Hiltunen, V., Seidl, W., Swietlicki, E., Teinilä, K., Sillanpää, M., Koponen, I. K., Paatero, J., Rosman, K., and Hämeri, K.: Chemical composition of aerosol during particle formation events in boreal forest, Tellus B, 53, 380393, 2001.

Makkonen, R., Asmi, A., Korhonen, H., Kokkola, H., Järvenoja, S., Räisänen, P., Lehtinen, K. E. J., Laaksonen, A., Kerminen, V.M., Jrvinen, H., Lohmann, U., Bennartz, R., Feichter, J., and Kulmala, M.: Sensitivity of aerosol concentrations and cloud properties to nucleation and secondary organic distribution in ECHAM5-HAM global circulation model, Atmos. Chem. Phys., 9, 1747-1766, doi:10.5194/acp-9-1747-2009, 2009

Matsunaga, S., Mochida, M., Saito, T., and Kawamura, K.: In situ measurement of isoprene in the marine air and surface seawater from the western North Pacific, Atmos. Environment, 36, 60516057, doi:10.1016/S1352-2310(02)00657-X, 2002.

Maus, S., MacMillan, S., Chernova, T., Choi, S., Dater, D., Golovkov, V., Lesur, V., Lowes, F., Lühr, H., Mai, W., McLean, S., Olsen, N., Rother, M., Sabaka, T., Thomson, A., and Zvereva, T.: The 10th generation international geomagnetic reference field, Phys. Earth Planet. Inter., 151, 320-322, 2005.

Merikanto, J., Spracklen, D. V., Mann, G. W., Pickering, S. J., and Carslaw, K. S.: Impact of nucleation on global CCN, Atmos. Chem. Phys., 9, 8601-8616, doi:10.5194/acp-9-8601-2009, 2009.

Merikanto, J., Spracklen, D. V., Pringle, K. J., and Carslaw, K. S.: Effects of boundary layer particle formation on cloud droplet number and changes in cloud albedo from 1850 to 2000, Atmos. Chem. Phys., 10, 695-705, doi:10.5194/acp-10-695-2010, 2010.

Metzger, A., Verheggen, B., Dommen, J., Duplissy, J., Prevot, A. S. H., Weingartner, E., Riipinen, I., Kulmala, M., Spracklen, D. V., Carslaw, K. S., and Baltensperger, U.: Evidence for the role of organics in aerosol particle formation under atmospheric conditions, Proc. Nat. Acad. Sci., 2010.

Miles, N. L., Verlinde, J., and Clothiaux, E. E.: Cloud droplet size distributions in low-level stratiform clouds, J. Atmos. Sci., 57, 295-311, 2000.

Murphy, S. M., Sorooshian, A., Kroll, J. H., Ng, N. L., Chhabra, P., Tong, C., Surratt, J. D., Knipping, E., Flagan, R. C., and Seinfeld, J. H.: Secondary aerosol formation from atmospheric reactions of aliphatic amines, Atmos. Chem. Phys., 7, 2313-2337, doi:10.5194/acp-7-2313-2007, 2007.

Neher, H. V. and Forbush, S. E.: Correlation of cosmic ray-intensity and solar activity, Phys. Rev. Lett., 1(5), 173-174, 1958.

O'Brien, K.: The theory of cosmic-ray and high-energy solarparticle transport in the atmosphere, in: The natural radiation environment VII. Elsevier. Seventh International Symposium on the Natural Radiation Environment, edited by: McLaughlin, J. P.,
Simopoulos, E. S., and Steinhäusler, F., Rhodes, Greece, 20-24 May, 2002, 2005.

O’Dowd, C. D., Geever, M., Hill, M. K., Smith, M. H., and Jennings, S. G.: New particle formation: Nucleation rates and spatial scales in the clean marine coastal environment, Geophys. Res. Lett., 25, 1661-1664, 1998.

O’Dowd, C. D., Jimenez, J. L., Bahreini, R., Flagan, R. C., Seinfeld, J. H., Hämeri, K., Pirjola, L., Kulmala, M., Jennings, S. G., and T., Hoffmann, T.: Marine aerosol formation from biogenic iodine emissions. Nature, 417, 632-636, 2002.

Petters, M. D. and Kreidenweis, S. M.: A single parameter representation of hygroscopic growth and cloud condensation nucleus activity, Atmos. Chem. Phys., 7, 1961-1971, doi:10.5194/acp-71961-2007, 2007.

Petters, M. D., Snider, J. R., Stevens, B., Vali, G., Faloona, I., and Russell, L. M.: Accumulation mode aerosol, pockets of open cells, and particle nucleation in the remote subtropical Pacific marine boundary layer, J. Geophys. Res., 111(D10), D02206, 2006.

Pierce, J. R. and Adams, P. J.: Uncertainty in global CCN concentrations from uncertain aerosol nucleation and primary emission rates, Atmos. Chem. Phys., 9, 1339-1356, doi:10.5194/acp-91339-2009, 2009.

Qian, S., Sakurai, H., and McMurry, P. H.: Characteristics of regional nucleation events in urban East St. Louis, Atmos. Environ., 41(19), 4119-4127, 2007.

Rinne, J., Ruuskanen, T. M., Reissell, A., Taipale, R., Hakola, H., and Kulmala, M.: On-line PTR-MS measurements of atmospheric concentrations of volatile organic compounds in a European boreal forest ecosystem, Boreal Environ. Res., 10, 425-436, 2005.

Roeckner, E., Bäuml, G., Bonaventura, L., Brokopf, R., Esch, M., Giorgetta, M., Hagemann, S., Kirchner, I., Kornblueh, L., Manzini, E., Rhodin, A., Schlese, U., Schulzweida, U., and Tompkins, A.: The atmospheric general circulation model ECHAM5. PART I: Model description, Tech. Rep. 349, Max Planck Institute for Meteorology, 2003.

Sakurai, H., Fink, M. A., McMurry, P. H., Mauldin, L., Moore, K. F., Smith, J. N., and Eisele, F. L.: Hygroscopicity and volatility of 4-10 nm particles during summertime atmospheric nucleation events in urban Atlanta, J. Geophys. Res., 110, D22S04, doi:10.1029/2005JD005918, 2005.

Sihto, S.-L., Kulmala, M., Kerminen, V.-M., Dal Maso, M., Petäjä, T., Riipinen, I., Korhonen, H., Arnold, F., Janson, R., Boy, M., Laaksonen, A., and Lehtinen, K. E. J.: Atmospheric sulphuric acid and aerosol formation: implications from atmospheric measurements for nucleation and early growth mechanisms, Atmos. Chem. Phys., 6, 4079-4091, doi:10.5194/acp-6-4079-2006, 2006.

Sihto, S.-L., Vuollekoski, H., Leppä, J., Riipinen, I., Kerminen, V.M., Korhonen, H., Lehtinen, K. E. J., Boy, M., and Kulmala, M.: Aerosol dynamics simulations on the connection of sulphuric acid and new particle formation, Atmos. Chem. Phys., 9, 2933 2947, doi:10.5194/acp-9-2933-2009, 2009.

Simmons, A. J. and Gibson ,J. K.: The ERA-40 project plan, ERA40 Project Report Series 1. Technical report, ECMWF, Shinfield Park, Reading, UK, 2000.

Spracklen, D. V., Carslaw, K. S., Kulmala, M., Kerminen, V., Sihto, S., Riipinen, I., Merikanto, J., Mann, G. W., Chipperfield, M. P., 
Wiedensohler, A., Birmili, W., and Lihavainen, H.: Contribution of particle formation to global cloud condensation nuclei concentrations. Geophys. Res. Lett., 35, L06808, 2008.

Spracklen, D. V., Carslaw, K. S., Kulmala, M., Kerminen, V.-M., Mann, G. W., and Sihto, S.-L.: The contribution of boundary layer nucleation events to total particle concentrations on regional and global scales, Atmos. Chem. Phys., 6, 5631-5648, doi:10.5194/acp-6-5631-2006, 2006.

Spracklen, D. V., Carslaw, K. S., Merikanto, J., Mann, G. W., Reddington, C. L., Pickering, S., Ogren, J. A., Andrews, E., Baltensperger, U., Weingartner, E., Boy, M., Kulmala, M., Laakso, L., Lihavainen, H., Kivekäs, N., Komppula, M., Mihalopoulos, N., Kouvarakis, G., Jennings, S. G., O’Dowd, C., Birmili, W., Wiedensohler, A., Weller, R., Gras, J., Laj, P., Sellegri, K., Bonn, B., Krejci, R., Laaksonen, A., Hamed, A., Minikin, A., Harrison, R. M., Talbot, R., and Sun, J.: Explaining global surface aerosol number concentrations in terms of primary emissions and particle formation, Atmos. Chem. Phys., 10, 4775-4793, doi:10.5194/acp-10-4775-2010, 2010.

Stier, P., Feichter, J., Kinne, S., Kloster, S., Vignati, E., Wilson, J., Ganzeveld, L., Tegen, I., Werner, M., Balkanski, Y., Schulz, M., Boucher, O., Minikin, A., and Petzold, A.: The aerosolclimate model ECHAM5-HAM, Atmos. Chem. Phys., 5, 11251156, doi:10.5194/acp-5-1125-2005, 2005.

Stier, P., Feichter, J., Kloster, S., Vignati, E., and Wilson, J.: Emission-induced nonlinearities in the global aerosol system: Results from the ECHAM5-HAM aerosol-climate model, J. Clim., 19, 3845, doi:10.1175/JCLI3772.1, 2006.

Stier, P., Seinfeld, J. H., Kinne, S., and Boucher, O.: Aerosol absorption and radiative forcing, Atmos. Chem. Phys., 7, 52375261, doi:10.5194/acp-7-5237-2007, 2007.

Sundqvist, H., Berge, E., and Kristjánsson, J. E.: Condensation and cloud parameterization studies with a mesoscale numerical weather prediction model, Mon. Weather Rev., 117, 1641-1657, 1989.

Taylor, K. E., Williamson, D., and Zwiers, F.: The sea surface temperature and sea-ice concentration boundary conditions for AMIP II simulations. Technical Report PCMDI Report No. 60, Program for Climate Model Diagnosis and Intercomparison, Lawrence Livermore National Laboratory, Livermore, California, USA, 2000.

Thornton, D. C., Bandy, A. R., Blomquist, B. W., Driedger, A. R., and Wade, T. P.: Sulfur dioxide distribution over the Pacific Ocean 1991-1996, J. Geophys. Res., 104, 5845-5854, 1999.

Tsyganenko, N. A.: Tsyganenko 2005 model and related software (GEOPACK), 2005.

Twomey, S. A.: The influence of pollution on the shortwave albedo of clouds, J. Atmos. Sci., 34, 1148-1152, 1977.

Vana, M., Kulmala, M., Dal Maso, M., Hõrrak, U., and Tamm, E.: Comparative study of nucleation mode aerosol particles and intermediate air ions formation events at three sites, J. Geophys. Res., 109, D17201, doi:10.1029/2003JD004413, 2004.
Vehkamäki, H., Kulmala, M., Napari, I., Lehtinen, K. E. J., Timmreck, C., Noppel, M., and Laaksonen, A.: An improved parameterization for sulfuric acid-water nucleation rates for tropospheric and stratospheric conditions, J. Geophys. Res., 107, 4622, doi:10.1029/2002JD002184, 2002.

Venzac, H., Sellegri, K., Laj, P., Villani, P., Bonasoni, P., Marinoni, A., Cristofanelli, P., Calzolari, F., Fuzzi, S., Decesari, S., Facchini, M.-C., Vuillermoz, E., and Verza, G. P.: High frequency new particle formation in the Himalayas, Proc. Nat. Acad. Sci., 105(41), 15666-15671, 2008.

Vignati, E., Wilson, J., and Stier, P.: M7: An efficient size-resolved aerosol microphysics module for large-scale aerosol transport models, J. Geophys. Res., 109, D22202, doi:10.1029/2003JD004485, 2004.

Wang, M. and Penner, J. E.: Aerosol indirect forcing in a global model with particle nucleation, Atmos. Chem. Phys., 9, 239-260, doi:10.5194/acp-9-239-2009, 2009.

Weber, R. J., Lee, S., Chen, G., Wang, B., Kapustin, V., Moore, K., Clarke, A. D., Mauldin, L., Kosciuch, E., Cantrell, C., Eisele, F., Thornton, D. C., Bandy, A. R., Sachse, G. W., and Fuelberg, H. E.: New particle formation in anthropogenic plumes advecting from Asia observed during TRACE-P, J. Geophys. Res., 108, 8814, doi:10.1029/2002JD003112, 2003.

Yu, F.: Effect of ammonia on new particle formation: A kinetic $\mathrm{H}_{2} \mathrm{SO}_{4}-\mathrm{H}_{2} \mathrm{O}-\mathrm{NH}_{3}$ nucleation model constrained by laboratory measurements, J. Geophys. Res., 111, D01204, 2005.

$\mathrm{Yu}, \mathrm{F}$.: Binary $\mathrm{H}_{2} \mathrm{SO}_{4}-\mathrm{H}_{2} \mathrm{O}$ homogeneous nucleation based on kinetic quasi-unary nucleation model: Look-up tables, J. Geophys. Res., 111, D04201, doi:10.1029/2005JD006358, 2006.

$\mathrm{Yu}, \mathrm{F}$.: Ion-mediated nucleation in the atmosphere: Key controlling parameters, implications, and look-up table, J. Geophys. Res., 115, D03206, doi:10.1029/2009JD012630, 2010.

Yu, F. and Luo, G.: Simulation of particle size distribution with a global aerosol model: contribution of nucleation to aerosol and CCN number concentrations, Atmos. Chem. Phys., 9, 76917710, doi:10.5194/acp-9-7691-2009, 2009.

Yu, F. and Turco, R.: Case studies of particle formation events observed in boreal forests: implications for nucleation mechanisms, Atmos. Chem. Phys., 8, 6085-6102, doi:10.5194/acp-86085-2008, 2008.

Yu, F., Wang, Z., Luo, G., and Turco, R.: Ion-mediated nucleation as an important global source of tropospheric aerosols, Atmos. Chem. Phys., 8, 2537-2554, doi:10.5194/acp-8-2537-2008, 2008.

Zhang, R., Suh, I., Zhao, J., Zhang, D., Fortner, E. C., Tie, X., Molina, L. T., and Molina, M. J.: Atmospheric new particle formation enhanced by organic acids, Science, 304(5676), 14871490, 2004. 